\title{
Propofol cardioplegia: A single-center, placebo-controlled, randomized controlled trial
}

\author{
Chris A. Rogers, PhD, ${ }^{a}$ Alan J. Bryan, DM, FRCS (CTh), ${ }^{b}$ Rachel Nash, MSc, ${ }^{a}$ M. Saadeh Suleiman, PhD, DSc, ${ }^{b}$ \\ Sarah Baos, PhD, ${ }^{\mathrm{a}}$ Zoe Plummer, MSc, PhD, ${ }^{a}$ James Hillier, MA, MBBS, FRCA, ${ }^{\mathrm{b}}$ \\ Ian Davies, MB, BCh(Wales), FRCA, Dip ABA, ${ }^{\mathrm{b}}$ Richard Downes, ACP, ${ }^{\mathrm{b}}$ Eamonn Nicholson, ACP, \\ Barnaby C. Reeves, DPhil, MSc, MA, ${ }^{a}$ and Gianni D. Angelini, MD, MCh, FRCS, FETCS ${ }^{\mathrm{b}}$
}

\begin{abstract}
Objectives: Cardiac surgery with cardiopulmonary bypass and cardioplegic arrest is an effective treatment for coronary artery and aortic valve diseases. However, the myocardium sustains reperfusion injury after ischemic cardioplegic arrest. Our objective was to assess the benefits of supplementing cardioplegia solution with the general anesthetic propofol in patients undergoing either coronary artery bypass grafting (CABG) or aortic valve replacement (AVR).

Methods: A single-center, double-blind randomized controlled trial was carried out to compare cardioplegia solution supplemented with propofol (concentration $6 \mu \mathrm{g} / \mathrm{mL}$ ) versus intralipid (placebo). The primary outcome was cardiac troponin $\mathrm{T}$ release over the first 48 hours after surgery.
\end{abstract}

Results: We recruited 101 participants (51 in the propofol group, 50 in the intralipid group); 61 underwent CABG and 40 underwent AVR. All participants were followed to 3 months. Cardiac troponin T release was on average $15 \%$ lower with propofol supplementation (geometric mean ratio, $0.85 ; 95 \%$ confidence interval $[\mathrm{CI}], 0.73-1.01 ; P=.051)$. There were no differences for CABG participants but propofol-supplemented participants undergoing AVR had poorer postoperative renal function (geometric mean ratio, 1.071; 95\% CI, 1.019-1.125; $P=.007$ ), with a trend toward longer intensive care stay (median, 89.5 vs 47.0 hours; hazard ratio, $0.58 ; 95 \% \mathrm{CI}, 0.31-1.09 ; P=.09$ ) and fewer with perfect health (based on the EQ-5D health utility index) at 3 months (odds ratio, 0.26 ; 95\% CI, 0.06-1.05; $P=.058)$ compared with the intralipid group. Safety profiles were similar. There were no deaths.

Conclusions: Propofol supplementation in cardioplegia appears to be cardioprotective. Its influence on early clinical outcomes may differ between CABG and AVR surgery. A larger, multicenter study is needed to confirm or refute these suggestions. (J Thorac Cardiovasc Surg 2015;150:1610-9)

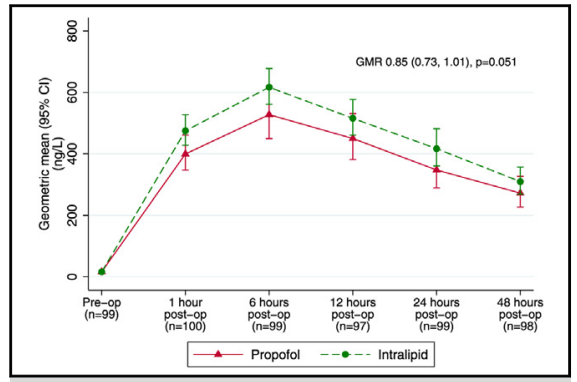

Cardiac troponin T level over time, expressed as geometric mean ratio (GMR) (95\% confidence interval) for propofol versus intralipid (placebo).

\section{Central Message}

Cardioplegia supplemented with propofol appears to be cardioprotective (ie, lower cardiac troponin level) in patients undergoing CABG or AVR surgery.

\section{Perspective}

This first randomized trial comparing cardioplegia supplemented with propofol versus intralipid suggests propofol may be cardioprotective in patients undergoing CABG or AVR (average $15 \%$ reduction in troponin $\mathrm{T}$ release during the first 48 hours after surgery). Its influence on early clinical outcomes may differ between CABG and AVR. A larger study is needed to confirm or refute these findings.

See Editorial Commentary page 1620 .
From the ${ }^{\mathrm{a} C l i n i c a l}$ Trials and Evaluation Unit, School of Clinical Sciences, University of Bristol, Bristol, United Kingdom; and ${ }^{b}$ Bristol Heart Institute, University Hospitals Bristol National Health Service Foundation Trust and University of Bristol, Bristol, United Kingdom.

Supported by a grant from the National Institute for Health Research (NIHR) Bristol Biomedical Research Unit in Cardiovascular Disease. B.C.R. is partially funded by this award, which also supported the research nurse team. G.D.A. is a British Heart Foundation (BHF) Professor of Cardiac Surgery and C.A.R. is a BHF Reader in Medical Statistics. R.N. is supported by a NIHR Research Methods Fellowship. The views and opinions expressed are those of the authors and do not necessarily reflect those of the NIHR, BHF, the UK National Health Service, or the Department of Health.
Received for publication Jan 5, 2015; revisions received May 28, 2015; accepted for publication June 20, 2015; available ahead of print Aug 6, 2015.

Address for reprints: Chris A. Rogers, PhD, Clinical Trials and Evaluation Unit, School of Clinical Sciences, University of Bristol, Level 7, Bristol Royal Infirmary, Marlborough St, Bristol, UK BS2 8HW (E-mail: chris.rogers@bristol.ac.uk). 0022-5223

Copyright $(2015$ by The American Association for Thoracic Surgery. Published by Elsevier Inc. This is an open access article under the CC BY-NC-ND license (http:// creativecommons.org/licenses/by-nc-nd/4.0/). http://dx.doi.org/10.1016/j.jtcvs.2015.06.044 


\section{Abbreviations and Acronyms \\ $\mathrm{AVR}=$ aortic valve replacement \\ $\mathrm{CABG}=$ coronary artery bypass grafting \\ $\mathrm{CPB}=$ cardiopulmonary bypass \\ cTNT $=$ cardiac troponin $\mathrm{T}$ \\ ICU = intensive care unit \\ GMR $=$ geometric mean ratio \\ MLHFQ $=$ Minnesota Living with Heart Failure Questionnaire \\ $\mathrm{mPTP}=$ mitochondrial permeability transition pore \\ $\mathrm{SAE} \quad=$ serious adverse event}

Myocardial protection with cardioplegic arrest remains the most popular technique during cardiac surgery with cardiopulmonary bypass (CPB). However, this intervention renders the heart globally ischemic and therefore susceptible to the damaging effects of reperfusion. ${ }^{1,2}$ Key events emanating from an ischemic insult include disruption to metabolic and ionic homeostasis. ${ }^{3}$ During ischemia, anaerobic metabolism leads to buildup of lactic acid (intracellular acidosis), which in turn causes a rise in intracellular sodium ion concentration via the sodium ion/hydrogen ion exchanger. Moreover, prolonged ischemia can also lead to calcium ion loading via the sodium ion/calcium ion exchanger. In addition to causing calcium ion loading, the ischemia-induced sodium ion accumulation could also contribute to osmotic-induced cell swelling, which can cause sarcolemmal damage. ${ }^{4-6}$ Upon reperfusion the renewed supply of oxygen leads to a surge in the formation of mitochondrial reactive oxygen species, as well as further significant calcium ion loading, both of which cause cardiomyocyte death by necrosis and apoptosis. $^{7,8}$ It is now established that this reperfusion injury is mediated by the opening of the mitochondrial permeability transition pore (mPTP), which is triggered by calcium ion overload and oxidative stress. ${ }^{9-11} \mathrm{~A}$ consequence of reperfusion injury is the recruitment of macrophages and neutrophils to the necrotic area, causing further damage to surrounding tissue. ${ }^{12,13}$ In view of the suboptimal protection conferred by current cardioplegic techniques, additional components have been sought that can reduce reactive oxygen species generation and calcium ion loading or, ultimately, inhibit the opening of mPTP. ${ }^{14}$

Propofol is widely used for the induction and maintenance of anesthesia during cardiac surgery. ${ }^{15}$ In addition to its anesthetic effect, extensive studies in animal models have demonstrated that direct coronary perfusion with propofol is cardioprotective during coronary reperfusion ${ }^{16}$ and such protection is mediated by improving tissue antioxidant capacity and reducing lipid peroxidation. ${ }^{17}$ Protection has been shown in patients with diabetes ${ }^{18}$ and with hypertrophic ${ }^{19}$ hearts. More importantly, a study in 2000 demonstrated that propofol at a clinically relevant concentration confers significant protection against global normothermic ischemia and during cold cardioplegic arrest, and that this effect was associated with less opening of mPTP. ${ }^{20}$ Moreover, the vehicle, intralipid, does not seem to be cardioprotective. ${ }^{20,21}$ Finally, a clinically relevant model has been used to support the inclusion of propofol in cardioplegia, ${ }^{22}$ prompting the design of this clinical trial to investigate its efficacy.

This study extends this work to a human clinical setting; the Propofol cardioplegia for Myocardial Protection (ProMPT) trial aims to test the hypothesis that supplementation of the cardioplegic solution with propofol is cardioprotective for patients undergoing isolated coronary artery bypass grafting $(\mathrm{CABG})$ or aortic valve replacement (AVR).

\section{METHODS \\ Trial Design}

The ProMPT trial is a single-center, double-blind, parallel-group, placebo-controlled randomized controlled trial. Participants were randomly allocated to propofol or intralipid (placebo) supplementation in a 1:1 ratio. This clinical trial is registered with Current Controlled Trials (http://www.controlled-trials.com/ISRCTN84968882).

\section{Participants}

Adults (aged $\geq 18$ and $\leq 80$ years) undergoing elective or urgent isolated CABG or AVR surgery with CPB were eligible to participate. Patients who had undergone previous surgery, were having combined CABG and AVR, an emergency or salvage operation, or were participating in another clinical trial were excluded. Patients with chronic renal failure requiring dialysis, congestive heart failure, poor left ventricular function, or an allergy to either propofol or intralipid were also excluded.

The study was conducted at the Bristol Heart Institute, a specialized regional cardiac surgery center in the United Kingdom. The study was approved by the West Midlands Research Ethics Committee (reference No. 09/H1208/60) and by the Medicines and Healthcare Products Regulatory Authority (Eudract: 2009-015779-28).

\section{Interventions}

Eligible patients (all under the care of a single surgeon [A.J.B.]) were randomized to cardioplegia supplementation with either propofol (at a concentration of $6 \mu \mathrm{g} / \mathrm{mL}$ ) or intralipid. A propofol concentration of $6 \mu \mathrm{g} / \mathrm{mL}$ does not exceed the level routinely observed in the circulation during induction or maintenance of anesthesia for cardiac surgery. ${ }^{23}$ The stock propofol $(10,000$ $\mu \mathrm{g} / \mathrm{mL}$ Fresenius Propoven $1 \%$ emulsion; Fresenius Kabi, Uppsala, Sweden) was diluted as recommended by the manufacturer to achieve a working solution of $2000 \mu \mathrm{g} / \mathrm{mL}$. The intralipid emulsion (Fresenius $10 \%$ ), was diluted in the same manner.

Warm blood cardioplegia (Calafiore formulation) with intermittent antegrade delivery was used for participants undergoing isolated CABG, and cold blood cardioplegia (Harefield Hospital formulation; Ivex Pharmaceuticals, Antrim, Northern Ireland) with either intermittent antegrade or antegrade and retrograde delivery was used for participants having $\mathrm{AVR}^{23}$ (see the Online Data Supplement for details). For participants undergoing isolated CABG, supplementation (propofol or equivalent volume of intralipid) was implemented by attaching an additional syringe pump to the line 
downstream of the blood oxygenator, with the syringe driver set to $0.6 \mathrm{~mL} /$ min resulting in a $6 \mu \mathrm{g} / \mathrm{mL}$ supplementation of the blood/cardioplegia mix during delivery. For participants undergoing isolated AVR the supplementation was added directly to a $500-\mathrm{mL}$ bag of $4: 1$ blood:cardioplegia solution. Information on propofol clearance is reported elsewhere. ${ }^{23}$

Anesthetic management adhered strictly to a locally agreed-upon protocol, and all other aspects of the patient's pre- and postoperative management was in accordance with existing protocols (see the Online Data Supplement and published descriptions ${ }^{24,25}$ for further details).

\section{Outcomes}

The primary outcome was myocardial injury, assessed by cardiac troponin T (cTnT) in serum from blood samples collected preoperatively and at 1, 6, 12, 24, and 48 hours after chest closure. Secondary outcomes were myocardial ischemic stress assessed in biopsies taken from left and right ventricles; systemic metabolic stress assessed by lactate; blood $\mathrm{pH}$; serum creatinine level; plasma propofol concentration; length of intensive care unit (ICU)/high dependency unit stay; clinical outcomes and serious adverse events (SAEs) to 3 months postsurgery; and patient health status at 3 months, measured using the EQ-5D health questionnaire, the Coronary Revascularization Outcome Questionnaire (CROQ) (CABG patients only), and the Minnesota Living with Heart Failure Questionnaire (MLHFQ) (AVR patients only). Blood samples for measuring lactate, $\mathrm{pH}$, and serum creatinine levels were taken at the same time points as for cTnT. Unexpected adverse events were coded using the Medical Dictionary for Regulatory Activities (version 14.1; McLean, Va). The evaluation of the effect of propofol supplementation on markers of myocardial ischemic stress will be reported separately.

Four secondary outcomes were removed from the protocol during the study due to insufficient funding to complete the laboratory analyses. These were concentration of microparticles in the circulation and measures of systemic oxidative stress, inflammatory response, and renal injury.

\section{Sample Size}

The trial was designed to test a superiority hypothesis. A study of $96 \mathrm{pa}-$ tients (48 per group: 24 CABG and 24 AVR) was required to detect a difference of 0.5 standard deviations (SDs) between propofol and intralipid supplementation within each surgical stratum with $80 \%$ power and $5 \%$ significance (2-sided test). Each biomarker was measured at baseline and 5 times postintervention, and a correlation of 0.5 between repeated measures was assumed. No interaction between the treatment and surgical stratum was anticipated.

\section{Randomization and Blinding}

The randomization scheme was stratified by operation (CABG or AVR) and minimized by diabetes status (oral medication/insulin or not). A secure internet-based system (http://www.sealedenvelope.com/) concealed allocations until sufficient information to identify the participant had been entered. Randomization took place after written informed consent had been obtained, and as close to surgery as possible. Randomization was carried out by staff not involved in data collection or patient care. Allocation details and materials required for the intervention (bag of intralipid or vial of propofol) were handed to the perfusionist in a sealed opaque envelope, and removed from the operating theatre at the end of the procedure. The required volume of emulsion was drawn-up in a syringe by the perfusionist and added to the cardioplegia solution. Because intralipid emulsion is used as a vehicle for propofol administration, the 2 interventions are visually indistinguishable. All other staff remained blinded to the treatment allocation for the duration of the study.

\section{Statistical Methods}

Analyses were performed on an intention-to-treat basis and directed by a prespecified statistical analysis plan. Continuous data are summarized as mean $\pm \mathrm{SD}$ or median (interquartile range) if distributions are skewed.
Categorical data are summarized as number (percentage). Primary and secondary outcomes were compared using logistic (binary variables), Cox proportional hazards (time to event variables), or linear mixed model (continuous variables measured at multiple time points) regression, with intralipid supplementation as the reference group. Model validity was checked using standard methods; if a model fitted poorly, transformations were explored. Outcomes analyzed on a logarithmic scale were transformed back to the original scale after analysis and results presented as geometric mean ratios (GMR). All analyses were adjusted for the stratification and minimization variables, operation, and diabetes status. See the Online Data Supplement for further details. The trial is not powered to detect differences in clinical outcomes and their frequencies are tabulated descriptively. Likelihood ratio tests were used to determine statistical significance.

Outcomes for CABG and AVR subgroups were compared by adding an allocation $\times$ surgery interaction term into the models. A subgroup analysis by diabetes status for the primary outcome was also prespecified. Subgroup-specific effects are reported if the interaction term was statistically significant at the $10 \%$ level. Four sensitivity analyses were specified in the analysis plan but not in the protocol (see Online Data Supplement for details).

All analyses were performed in SAS version 9.3 (SAS Institute Inc, Cary, NC) and Stata version 13.0 (StataCorp LP, College Station, Tex).

\section{RESULTS \\ Recruitment}

Between March 2010 and July 2012, 203 patients were screened for inclusion in the trial, 44 of whom were ineligible. Of the 159 eligible patients screened, 101 agreed to participate and were randomized; 51 to receive propofol and 50 to receive intralipid (Figure 1). Two participants (1 allocated to receive propofol and 1 allocated to receive intralipid) were found to be ineligible during surgery because their left ventricular function was worse than anticipated. However, these participants consented for data collection to continue.

The primary analysis includes all randomized participants. There were 7 major protocol violations: 6 participants did not receive any trial treatment and 1 participant allocated to the intralipid group received propofol (Tables E1 and E2). Therefore, 95 participants were included in the per-protocol analysis. Participants were followed for 3 months after randomization. Safety data at 3 months were available on all participants and health status questionnaires for 100 out of 101 participants.

\section{Baseline Data}

The median age of participants was 67.9 years (IQR, 63.973.7 years) and 77 out of $101(76 \%)$ were male (Table 1). The median European System for Cardiac Operative Risk Evaluation (version 1) score was 4 (IQR, 2-5). Overall, 61 out of $101(60 \%)$ participants underwent CABG and 40 out of $101(40 \%)$ participants underwent AVR surgery. The majority of participants did not have diabetes (80 out of $101 ; 79 \%$ ). By chance, participants allocated to propofol supplementation were slightly younger (median age, $66.5 \mathrm{vs}$ 70.6 years) and included more current or exsmokers (34 out of $51[60 \%]$ vs 26 out of $50[52 \%])$ and more being treated for hypertension (44 out of 51 [86\%] vs 35 out of 50 [70\%]) than participants allocated to intralipid. Medications before 


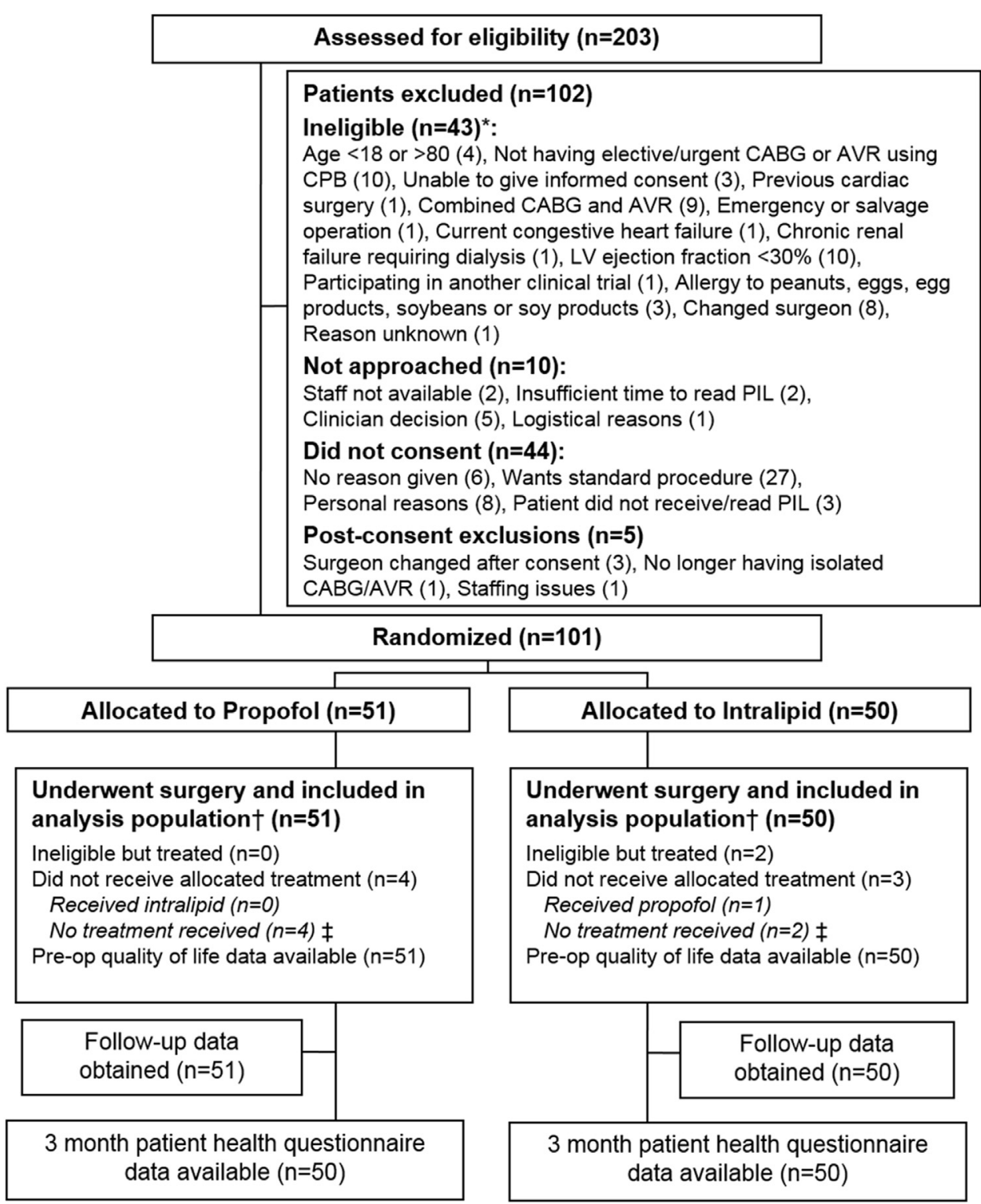

FIGURE 1. Participant flow. $C A B G$, Coronary artery bypass grafting; $A V R$, aortic valve replacement; $C P B$, cardiopulmonary bypass; $L V$, left ventricular; $P I L$, Patient Information Leaflet. *Patients may be ineligible for $>1$ reason. $\nmid$ Safety population identical to analysis population. $\ddagger$ Two participants $(1$ randomized to propofol, 1 to intralipid) were withdrawn before surgery, but willing to continue with trial data collection. Both were found to be ineligible after randomization.

surgery are described in Table E3 and participant demographics by surgical stratum are given in Table E4.

\section{Operative Details}

Operative, crossclamp, and total bypass times were similar in the 2 groups (Table 1). On average the surgery took 3 hours 10 minutes and the duration of $\mathrm{CPB}$ was just under 90 minutes. On average, total bypass time was $20 \mathrm{mi}-$ nutes longer for participants undergoing AVR compared with CABG and the crossclamp time was almost 30 minutes longer, although the overall operation time was similar
(Table E5). Overall, 95 out of $101(94 \%)$ participants received tranexamic acid (median, $2 \mathrm{~g}$ in both groups) and 9 out of $101(9 \%)$ required inotropic support (Table E6). The majority of participants having CABG had $\geq 3$ grafts (22 out of 31 [71\%] in the propofol group vs 23 out of 30 [77\%] in the intralipid group). All participants received blood cardioplegia. Both groups had circulating propofol in the blood in the cardioplegia circuit due to the propofol administered during anesthesia but, as expected, the mean $\pm \mathrm{SD}$ concentration was higher in the propofol group than in the intralipid group $(9.92 \pm 1.38$ vs $4.46 \pm 1.80$ 
TABLE 1. Participant demographic characteristics and past history, intraoperative history, and postoperative details

\begin{tabular}{|c|c|c|c|}
\hline Characteristic & $\begin{array}{c}\text { Randomized to } \\
\text { propofol }(\mathbf{n}=\mathbf{5 1})\end{array}$ & $\begin{array}{c}\text { Randomized to } \\
\text { intralipid }(\mathbf{n}=\mathbf{5 0})\end{array}$ & $\begin{array}{c}\text { Overall } \\
(\mathbf{n}=101)\end{array}$ \\
\hline \multicolumn{4}{|l|}{ Demographic and past history } \\
\hline Age (y) & $66.5(62.5-72.1)$ & $70.6(65.0-76.4)$ & $67.9(63.9-73.7)$ \\
\hline Male & $41(80)$ & $36(72)$ & $77(76)$ \\
\hline Body mass index & $29.3 \pm 5.6$ & $27.1 \pm 3.8$ & $28.2 \pm 4.9$ \\
\hline Diabetic & $11(22)$ & $10(20)$ & $21(21)$ \\
\hline $\begin{array}{l}\text { Estimated glomerular filtration rate } \\
\qquad\left(\mathrm{mL} / \mathrm{min} / 1.73 \mathrm{~m}^{2}\right)\end{array}$ & $69.9 \pm 20.0$ & $72.2 \pm 14.8$ & $71.0 \pm 17.6$ \\
\hline \multicolumn{4}{|l|}{ Cardiac history } \\
\hline $\begin{array}{l}\text { European System for Cardiac Operative } \\
\text { Risk Evaluation score }\end{array}$ & $4(2.0-5.0)$ & $5(3.0-6.0)$ & $4(2.0-5.0)$ \\
\hline \multicolumn{4}{|l|}{ No. of vessels with coronary disease* } \\
\hline None & $20(39)$ & $19(38)$ & $39(39)$ \\
\hline Single & $1(2)$ & $2(4)$ & $3(3)$ \\
\hline Double & $6(12)$ & $12(24)$ & $18(18)$ \\
\hline Triple & $24(47)$ & $17(34)$ & $41(41)$ \\
\hline$>50 \%$ disease in left main stem & $9(18)$ & $5(10)$ & $14(14)$ \\
\hline \multicolumn{4}{|l|}{ Noncardiac history } \\
\hline \multicolumn{4}{|l|}{ Smoking status } \\
\hline Smoker & $5(10)$ & $5(10)$ & $10(10)$ \\
\hline Nonsmoker & $17(33)$ & $24(48)$ & $41(41)$ \\
\hline Exsmoker $>1$ mo & $29(57)$ & $21(42)$ & $50(50)$ \\
\hline Family history & $24(47)$ & $31(62)$ & $55(54)$ \\
\hline Hypertension requiring treatment & $44(86)$ & $35(70)$ & $79(78)$ \\
\hline Stroke or transient ischemic attacks & $2(4)$ & $4(8)$ & $6(6)$ \\
\hline Elective procedure & $47(92)$ & $46(92)$ & $93(92)$ \\
\hline \multicolumn{4}{|l|}{ Intraoperative details } \\
\hline Operation duration (min) & $191.0 \pm 32.2$ & $190.1 \pm 29.7$ & $190.5 \pm 30.8$ \\
\hline Cumulative crossclamp time (min) $\dagger$ & $54.0 \pm 19.7$ & $53.4 \pm 16.2$ & $53.7 \pm 18.0$ \\
\hline Total bypass time $(\mathrm{min}) \dagger$ & $88.2 \pm 22.0$ & $88.8 \pm 19.0$ & $88.5 \pm 20.4$ \\
\hline \multicolumn{4}{|l|}{ Myocardial protection } \\
\hline $\begin{array}{l}\text { Concentration of propofol in cardioplegia } \\
(\mu \mathrm{g} / \mathrm{mL}) \ddagger\end{array}$ & $9.92 \pm 1.38$ & $4.46 \pm 1.80$ & $7.16 \pm 3.17$ \\
\hline \multicolumn{4}{|l|}{$\begin{array}{l}\text { Concentration of systemic (arterial line) } \\
\text { plasma propofol }(\mu \mathrm{g} / \mathrm{mL})\end{array}$} \\
\hline Before crossclamp $\ddagger$ & $3.92 \pm 1.38$ & $4.34 \pm 1.36$ & $4.13 \pm 1.37$ \\
\hline During crossclamp $\ddagger$ & $4.16 \pm 1.20$ & $4.36 \pm 1.23$ & $4.26 \pm 1.21$ \\
\hline 10 min after crossclamp release $\ddagger$ & $4.07 \pm 1.10$ & $4.51 \pm 1.18$ & $4.29 \pm 1.16$ \\
\hline CABG surgery & $31(61)$ & $30(60)$ & $61(60)$ \\
\hline \multicolumn{4}{|l|}{ No. of grafts } \\
\hline 1 & $1(3)$ & $0(0)$ & $1(2)$ \\
\hline 2 & $8(26)$ & $7(23)$ & $15(25)$ \\
\hline 3 & $16(52)$ & $18(60)$ & $34(56)$ \\
\hline 4 & $6(19)$ & $5(17)$ & $11(18)$ \\
\hline $\begin{array}{l}\text { Estimated volume of cardioplegia } \\
\text { given }(\mathrm{mL}) \S\end{array}$ & $1207 \pm 355$ & $1197 \pm 333$ & $1202 \pm 341$ \\
\hline AVR surgery & $20(39)$ & $20(40)$ & $40(40)$ \\
\hline $\begin{array}{l}\text { Total volume of cold cardioplegia } \\
\text { given }(\mathrm{mL})\end{array}$ & $1790.2 \pm 322.0$ & $1782.4 \pm 264.1$ & $1786.3 \pm 290.7$ \\
\hline \multicolumn{4}{|l|}{ Postoperative details } \\
\hline Total ventilation time $(\mathrm{h}) \|$ & $6.8(4.9-8.8)$ & $7.2(5.6-10.5)$ & $7.0(5.2-8.8)$ \\
\hline \multicolumn{4}{|l|}{ Time in intensive care unit $(\mathrm{h}) \mathbb{\Upsilon}$} \\
\hline CABG participants $(\mathrm{n}=61)$ & $69.3(47.8-113.0)$ & $87.3(68.0-114.0)$ & $75.9(49.0-113.0)$ \\
\hline AVR participants $(n=40)$ & $89.5(46.9-120.5)$ & $47.0(43.0-89.5)$ & $49.0(46.0-100.3)$ \\
\hline
\end{tabular}


TABLE 1. Continued

\begin{tabular}{|c|c|c|c|}
\hline Characteristic & $\begin{array}{c}\text { Randomized to } \\
\text { propofol }(\mathbf{n}=\mathbf{5 1})\end{array}$ & $\begin{array}{c}\text { Randomized to } \\
\text { intralipid }(\mathbf{n}=\mathbf{5 0})\end{array}$ & $\begin{array}{c}\text { Overall } \\
(n=101)\end{array}$ \\
\hline Time on ward predischarge (h)\# & $73.5(43.2-115.0)$ & $92.8(51.0-139.0)$ & $91.0(49.8-120.0)$ \\
\hline Length of hospital stay (d) & $7(6-8)$ & $6(5-9)$ & $6(6-9)$ \\
\hline \multicolumn{4}{|c|}{ 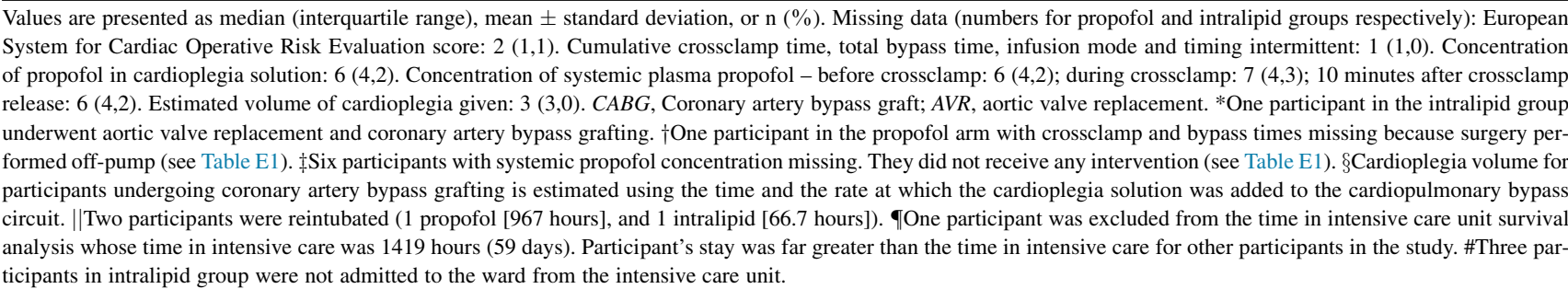 } \\
\hline
\end{tabular}

$\mu \mathrm{g} / \mathrm{mL})$. In contrast, the systemic propofol concentrations in blood samples taken from the diagnostic radial arterial line during aortic crossclamp were similar (mean difference (MD), $-0.02 \mu \mathrm{g} / \mathrm{mL} ; 95 \%$ confidence interval (CI), -0.41 to $0.37 ; P=.92)$, as were the propofol concentrations in samples taken after crossclamp release (MD, -0.1 $5 \mu \mathrm{g} / \mathrm{mL} ; 95 \% \mathrm{CI},-0.51$ to $0.22 ; P=.39$ ).

\section{Postoperative Outcomes}

cTnT concentrations are illustrated in Figure 2 and summarized in Table E7. Preoperative concentrations were similar in the 2 groups (30 out of 50 [60\%] below the detectable limit, median concentration $21 \mathrm{ng} / \mathrm{L}$ among participants with detectable concentrations in the propofol group vs 34 out of 49 [69\%] and $20 \mathrm{ng} / \mathrm{L}$ in the intralipid group). cTnT concentrations rose following surgery peaking at 6 hours and were, on average, $15 \%$ lower in the propofol group (GMR, 0.85; 95\% CI, 0.73-1.01; $P=.051)$. Average cTnT concentrations were similar across the 2 surgical strata (test for

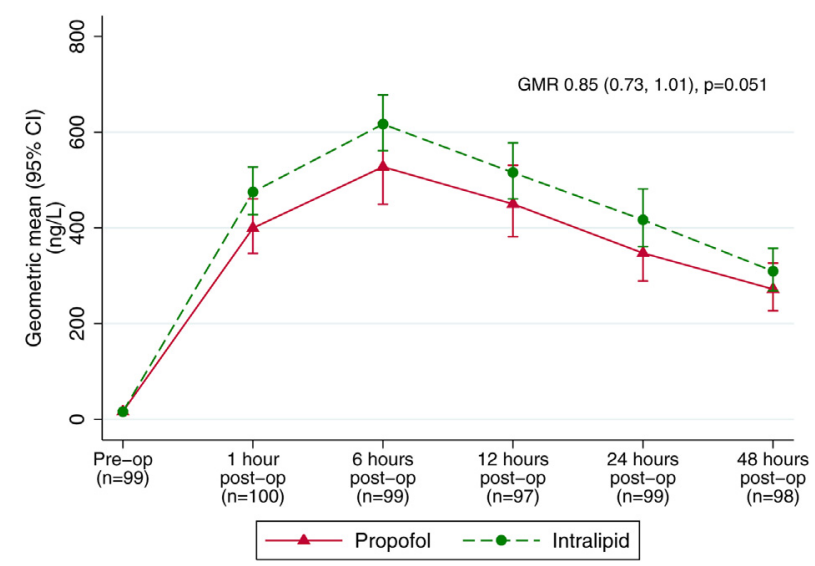

FIGURE 2. Cardiac troponin T response over time. Geometric mean and $95 \%$ confidence interval $(C I)$ of cardiac troponin $\mathrm{T}$ level at each time point and geometric mean ratio $(G M R)$ for the effect of propofol versus intralipid on cardiac troponin T release (95\% CI). Pre-op, Preoperative; Post-op, postoperative. interaction $P=.36$ ) and by diabetes status (Figure E1). The preplanned sensitivity analysis did not alter the study conclusions (Figure E2).

In contrast, postoperative lactate concentrations and blood $\mathrm{pH}$ did not differ between the groups; lactate was, on average, 7\% higher in the propofol group (GMR, 1.07; $95 \% \mathrm{CI}, 0.98-1.18 ; P=.14)$ and the $\mathrm{pH}$ was slightly lower (MD, $-0.007 ; 95 \%$ CI, -0.018 to $0.003 ; P=.17$; Figure 3 and Table E8).

The effect of propofol supplementation on postoperative renal function and on length of ICU/high dependency unit stay differed between CABG and AVR participants (test for interactions, $P=.069$ and $P=.068$ for creatinine and ICU stay, respectively). Postoperative creatinine concentrations were similar in the 2 groups for participants undergoing CABG (GMR, $1.010 ; 95 \%$ CI, 0.970-1.051; $P=.62$ ), but higher in the propofol group for participants undergoing AVR surgery (GMR, 1.071; 95\% CI, 1.019-1.125; $P=.007$; Figure 3 and Table E9). In participants who underwent CABG the duration of ICU stay in the propofol group tended to be shorter, whereas for participants undergoing AVR surgery it was longer, but for both subgroups the difference between the propofol and intralipid groups was not statistically significant (CABG: median 69.3 vs 87.3 hours; hazard ratio $(\mathrm{HR}) ; 1.25 ; 95 \% \mathrm{CI}, 0.75$ 2.09; $P=.40$ and AVR: median 89.5 vs 47.0 hours; HR, 0.58; 95\% CI, 0.31-1.09; $P=.09$ ) (Table 1).

The surgery-specific health status scores, derived from the CROQ, MLHFQ, and EQ-5D visual analog scale, were similar in the propofol and intralipid groups (see Figure E3 and Tables E10-E12). The proportion of participants reporting perfect health on the EQ-5D (utility score of 1) was similar in the 2 groups for participants undergoing CABG surgery (12 out of 30 [40\%] in propofol group vs 9 out of 29 [31\%] in the intralipid group, odds ratio (OR) $1.31 ; 95 \%$ CI, 0.47-3.62; $P=.61)$. However, of the participants undergoing AVR surgery proportionally fewer had perfect health in the propofol group (5 out of 20 [25\%] vs 10 out of 

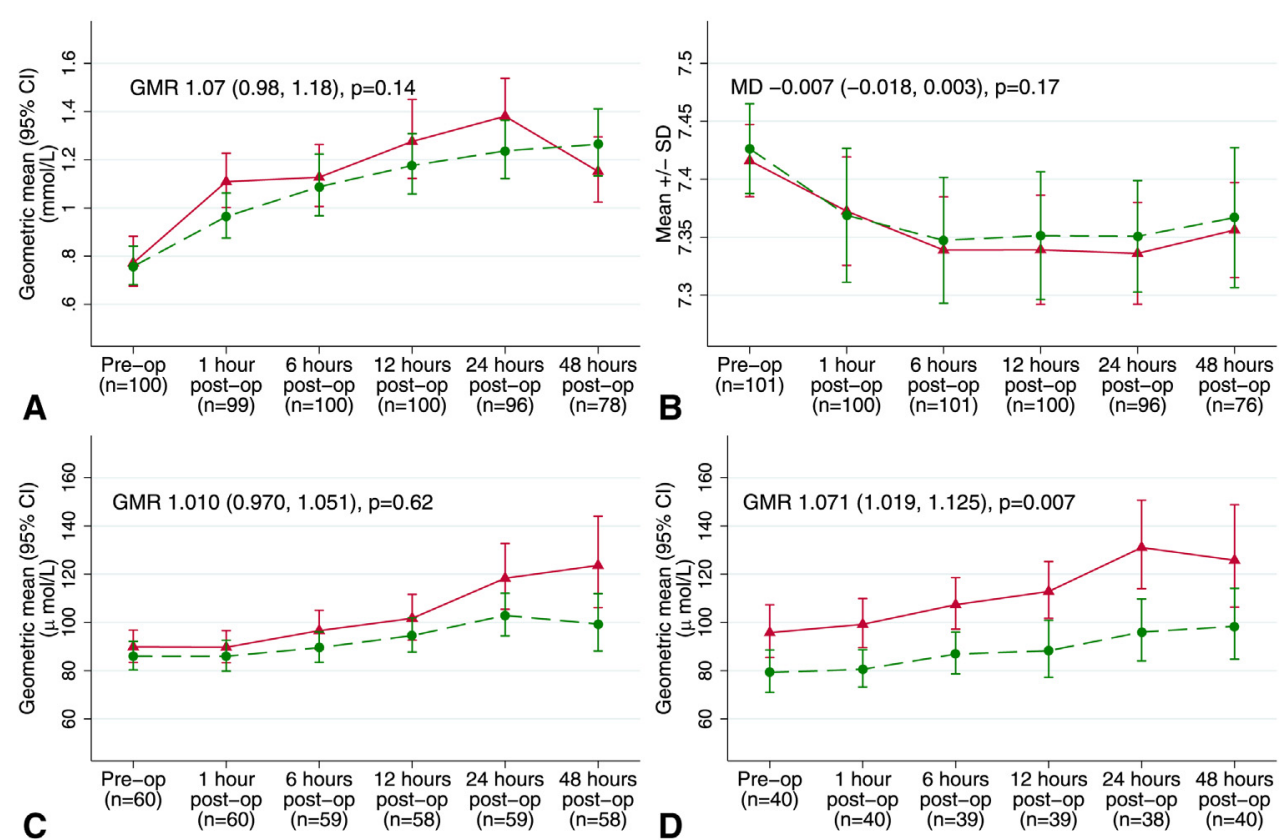

$$
\longrightarrow \text { Propofol }--0-\text { Intralipid }
$$

FIGURE 3. Concentrations over time. A, Lactate (all participants). B, pH Levels (all participants), C, Creatinine (coronary artery bypass grafting [CABG] participants). D, Creatinine (aortic valve replacement [AVR] participants). Geometric mean and $95 \%$ confidence interval $(\mathrm{CI})$ at each study time point by group, and geometric mean ratio $(G M R)$ and $95 \% \mathrm{CI}$ for the effect of propofol versus intralipid on lactate (all participants), creatinine (CABG participants), and creatinine (AVR participants). Mean and standard deviation $(S D)$ at each study time point by group, and mean difference $(M D)$ and $95 \% \mathrm{CI}$ for the effect of propofol versus intralipid on $\mathrm{pH}$ level (all participants). Pre-op, Preoperative; Post-op, postoperative.

19 [53\%]; OR, 0.26; 95\% CI, 0.06-1.05; $P=.058)$. The test for interaction between treatment and surgery was $P=.067$. The sensitivity analysis, assuming missing scores in MLHFQ indicated poor quality of life, was consistent with the primary analyses (Figure E4).

\section{Adverse Events}

Overall, there were 211 postoperative complications (ie, adverse events) in 87 participants; 99 complications in 44 out of $51(86 \%)$ participants in the propofol group and 112 complications in 43 out of $50(86 \%)$ participants in the intralipid group (OR for 1 or more complications, 1.03 ; $95 \%$ CI, $0.33-3.21 ; P=.95$ ). Of these complications, 43 (26 propofol vs 17 intralipid) were classed as SAEs. Twenty-two participants (11 in each group) experienced one or more SAEs in the 3 months following surgery (OR for 1 or more SAEs, 0.97 ; 95\% CI, 0.36-2.56; $P=.94)$. Of the 211 complications reported, 200 were expected (ie, they were listed in the study protocol) and 11 were unexpected. Ten of the 11 unexpected events were classed as serious compared with 33 out of $200(17 \%)$ of expected events (Table 2). Additional details on the unexpected events are given in Table E13. There were no deaths. Event rates were similar across both groups for the majority of complications. Participants in the intralipid group were more likely to experience a pneumothorax or pulmonary effusion requiring drainage ( 7 out of 50 [14\%] vs 1 out of $51[2 \%]$ ) or an infective complication (18 out of $50[36 \%]$ vs 9 out of $51[18 \%]$ ). The differences in the frequencies of these complications were reflected in slightly longer intubation times and longer ward stays in the intralipid group (median intubation time, 6.8 vs 7.2 hours; median ward stay, 73.5 vs 92.8 hours) (Table 1).

\section{DISCUSSION}

We believe that this is the first randomized controlled trial to evaluate the supplementation of propofol in cardioplegia solution in patients undergoing CABG or AVR surgery. The study suggests that the addition of propofol to the cardioplegia solution protects the heart against ischemic reperfusion injury, as shown by the average $15 \%$ lower cTnT release over the first 48 hours after surgery, which equates to an average difference of between 60 and $90 \mathrm{ng} / \mathrm{L}$ across the first 48 hours. Previous studies have suggested that troponin release is predictive of outcome. Soraas and colleagues ${ }^{26}$ demonstrated that the long-term mortality risk increases by $31 \% \quad(95 \%$ CI, $+13 \%$ to $+51 \%$ ) for every $1 \mu \mathrm{g} / \mathrm{L}$ rise in peak cTnT and Mohammed and colleagues ${ }^{27}$ suggested that cTnT is 
TABLE 2. Postoperative complications

\begin{tabular}{|c|c|c|c|c|c|c|c|c|}
\hline \multirow[b]{3}{*}{ Event (expected or unexpected) } & \multicolumn{4}{|c|}{ Randomized to propofol $(n=51)$} & \multicolumn{4}{|c|}{ Randomized to intralipid $(n=50)$} \\
\hline & \multicolumn{2}{|l|}{ All events } & \multicolumn{2}{|l|}{ SAEs } & \multicolumn{2}{|l|}{ All events } & \multicolumn{2}{|l|}{ SAEs } \\
\hline & Events/patients & $\%$ & Events/patients & $\%$ & Events/patients & $\%$ & Events/patients & $\%$ \\
\hline Any event (expected or unexpected) & $99 / 44$ & 86 & $26 / 11$ & 22 & $112 / 43$ & 86 & $17 / 11$ & 22 \\
\hline \multicolumn{9}{|l|}{ Expected events listed in study protocol } \\
\hline Myocardial Infarction & $2 / 2$ & 4 & $1 / 1$ & 2 & $0 / 0$ & 0 & $0 / 0$ & 0 \\
\hline Arrhythmias & $30 / 24$ & 47 & $4 / 3$ & 6 & $33 / 26$ & 52 & $0 / 0$ & 0 \\
\hline $\begin{array}{c}\text { Supraventricular tachycardia/atrial } \\
\text { fibrillation requiring treatment }\end{array}$ & $25 / 21$ & 41 & $3 / 2$ & 4 & $24 / 24 *$ & 48 & $0 / 0$ & 0 \\
\hline $\begin{array}{l}\text { Ventricular fibrillation/ventricular } \\
\text { tachycardia requiring intervention }\end{array}$ & $0 / 0$ & 0 & $0 / 0$ & 0 & $1 / 1$ & 2 & $0 / 0$ & 0 \\
\hline New pacing & $5 / 5 \dagger$ & 10 & $1 / 1$ & 2 & $8 / 8 \dagger$ & 16 & $0 / 0$ & 0 \\
\hline Pacing permanent & $1 / 1$ & 2 & $1 / 1$ & 2 & $0 / 0$ & 0 & $0 / 0$ & 0 \\
\hline Hemodynamic support & $32 / 26$ & 51 & $3 / 2$ & 4 & $32 / 28$ & 56 & $0 / 0$ & 0 \\
\hline Inotropes used & $17 / 16^{*}$ & 31 & $1 / 1$ & 2 & $18 / 17^{*}$ & 34 & $0 / 0$ & 0 \\
\hline Intra-aortic balloon pump used & $1 / 1$ & 2 & $1 / 1$ & 2 & $0 / 0$ & 0 & $0 / 0$ & 0 \\
\hline Vasodilators used & $13 / 13 \dagger$ & 25 & $0 / 0$ & 0 & $13 / 13+, \ddagger$ & 26 & $0 / 0$ & 0 \\
\hline Low cardiac output & $1 / 1$ & 2 & $1 / 1$ & 2 & $1 / 1$ & 2 & $0 / 0$ & 0 \\
\hline Pulmonary complications & $10 / 8$ & 16 & $3 / 2$ & 4 & $14 / 11$ & 22 & $4 / 4$ & 8 \\
\hline Reintubation/ventilation & $1 / 1$ & 2 & $1 / 1$ & 2 & $1 / 1$ & 2 & $0 / 0$ & 0 \\
\hline Tracheostomy & $1 / 1$ & 2 & $1 / 1$ & 2 & $0 / 0$ & 0 & $0 / 0$ & 0 \\
\hline $\begin{array}{l}\text { Mask continuous positive airway } \\
\text { pressure }\end{array}$ & $7 / 7$ & 14 & $0 / 0$ & 0 & $5 / 4$ & 8 & $0 / 0$ & 0 \\
\hline $\begin{array}{l}\text { Pneumothorax or effusion requiring } \\
\text { drainage }\end{array}$ & $1 / 1$ & 2 & $1 / 1$ & 2 & $8 / 7$ & 14 & $4 / 4$ & 8 \\
\hline Thromboembolic complications & $1 / 1$ & 2 & $1 / 1$ & 2 & $1 / 1$ & 2 & $1 / 1$ & 2 \\
\hline Deep vein thrombosis & $0 / 0$ & 0 & $0 / 0$ & 0 & $1 / 1$ & 2 & $1 / 1$ & 2 \\
\hline Pulmonary embolism & $1 / 1$ & 2 & $1 / 1$ & 2 & $0 / 0$ & 0 & $0 / 0$ & 0 \\
\hline Infective complications & $11 / 9 \dagger$ & 18 & $3 / 3 \dagger$ & 6 & $21 / 18 \dagger$ & 36 & $4 / 4$ & 8 \\
\hline Sepsis & $5 / 4 \dagger$ & $8 \%$ & $0 / 0$ & 0 & $13 / 11$ & 23 & $0 / 0$ & 0 \\
\hline Respiratory infection & $5 / 5$ & 10 & $0 / 0$ & 0 & $12 / 10$ & 20 & $0 / 0$ & 0 \\
\hline New hemofiltration/dialysis & $1 / 1$ & 2 & $1 / 1$ & 2 & $1 / 1$ & 2 & $0 / 0$ & 0 \\
\hline Gastrointestinal complications & $5 / 5$ & 10 & $4 / 4$ & 8 & $2 / 2$ & 4 & $2 / 2$ & 4 \\
\hline $\begin{array}{l}\text { Peptic ulcer/gastrointestinal bleed/ } \\
\text { perforation }\end{array}$ & $2 / 2$ & 4 & $2 / 2$ & 4 & $0 / 0$ & 0 & $0 / 0$ & 0 \\
\hline Other gastrointestinal complications & $3 / 3$ & 6 & $2 / 2$ & 4 & $2 / 2$ & 4 & $2 / 2$ & 4 \\
\hline Permanent stroke & $0 / 0$ & 0 & $0 / 0$ & 0 & $1 / 1 \dagger$ & 2 & $1 / 1 \dagger$ & 2 \\
\hline Wound dehiscence requiring reoperation & $0 / 0$ & 0 & $0 / 0$ & 0 & $1 / 1$ & 2 & $1 / 1$ & 2 \\
\hline Chest reopened due to bleeding & $0 / 0$ & 0 & $0 / 0$ & 0 & $2 / 2$ & 4 & $0 / 0$ & 0 \\
\hline Any expected event & $92 / 43$ & 84 & $20 / 10$ & 20 & $108 / 43$ & 86 & $13 / 10$ & 20 \\
\hline \multicolumn{9}{|l|}{ Unexpected events not listed in study protocol } \\
\hline Bradycardia & $0 / 0$ & 0 & $0 / 0$ & 0 & $1 / 1$ & 2 & $1 / 1$ & 2 \\
\hline Cardiac failure congestive & $1 / 1$ & 2 & $1 / 1$ & 2 & $1 / 1$ & 2 & $1 / 1$ & 2 \\
\hline Chest pain & $1 / 1$ & 2 & $1 / 1$ & 2 & $0 / 0$ & 0 & $0 / 0$ & 0 \\
\hline Cholecystectomy & $0 / 0$ & 0 & $0 / 0$ & 0 & $1 / 1$ & 2 & $1 / 1$ & 2 \\
\hline Diverticulum & $1 / 1$ & 2 & $1 / 1$ & 2 & $0 / 0$ & 0 & $0 / 0$ & 0 \\
\hline Maculopathy & $1 / 1$ & 2 & $1 / 1$ & 2 & $0 / 0$ & 0 & $0 / 0$ & 0 \\
\hline Paraesthesia & $0 / 0$ & 0 & $0 / 0$ & 0 & $1 / 1$ & 2 & $1 / 1$ & 2 \\
\hline Peripheral ischemia & $1 / 1$ & 2 & $1 / 1$ & 2 & $0 / 0$ & 0 & $0 / 0$ & 0 \\
\hline Postprocedural hemorrhage & $1 / 1$ & 2 & $0 / 0$ & 0 & $0 / 0$ & 0 & $0 / 0$ & 0 \\
\hline Renal failure acute & $1 / 1$ & 2 & $1 / 1$ & 2 & $0 / 0$ & 0 & $0 / 0$ & 0 \\
\hline Any unexpected event & $7 / 6$ & 12 & $6 / 5$ & 10 & $4 / 4$ & 8 & $4 / 4$ & 8 \\
\hline
\end{tabular}

Serious adverse events postdischarge included for the propofol group: 2 gastrointestinal bleeds, 2 episodes of atrial fibrillation (1 participant), 1 myocardial infarction, 1 pneumothorax, 1 pulmonary embolism, 1 infective complication, 1 diverticulum, 1 chest pain, 1 maculopathy, 1 congestive cardiac failure and 1 renal failure. Serious adverse events postdischarge included for the intralipid group: 3 pneumothorax, 2 infective complications, 1 stroke, 1 cholecystectomy, and 1 congestive cardiac failure. Missing data (numbers for propofol and intralipid groups respectively): Sepsis: $4(1,3)$. SAE, Serious adverse event. *Two participants had study treatment discontinued. $\dagger$ One participant had study treatment discontinued. $\ddagger$ One participant received alternative treatment to that allocated. 
independently prognostic for death, heart failure, or need for vasopressor agents (OR, 2.57; 95\% CI, 1.9-3.4), with a median cTnT of $1.01 \mathrm{ng} / \mathrm{mL}$ in those who did not experience the outcome versus $1.6 \mathrm{ng} / \mathrm{mL}$ in those who did.

The data suggest a possible difference between the CABG and AVR subgroups in the effect of propofol on postoperative renal function, ICU stay, and health utility status at 3 months: serum creatinine concentrations were on average $7 \%$ higher in the propofol group in participants undergoing AVR surgery, which equates to a difference of approximately $30 \mu \mathrm{mol} / \mathrm{L}$ at 48 hours. Participants undergoing AVR allocated to propofol stayed in the ICU on average 42 hours longer than those allocated to intralipid, and a greater proportion had less-than-perfect health at 3 months. These trends were not observed in the participants undergoing CABG surgery.

It is possible that the differences observed for the AVR group occurred by chance because the short half-life of propofol makes it difficult to give a plausible biological explanation for differences arising $\geq 48$ hours after leaving the operating theatre. Alternatively, propofol, by lowering blood pressure, may reduce renal perfusion and negatively affect renal function. Also, the higher proportion of AVR participants with risk factors for acute kidney injury allocated to propofol supplementation may explain the difference. In particular, there were more participants with chronic obstructive pulmonary disease, diabetes, hypertension, or female gender in the propofol group (17 out of 20 [85\%] vs 15 out of $20[75 \%])^{28}$ and the mean baseline estimated glomerular filtration rate was lower $(62.8$ vs $67.5 \mathrm{~mL} /$ $\min / 1.73 \mathrm{~m}^{2}$ ).

Complications after cardiac surgery are common. The majority of patients $(86 \%)$ experienced at least 1 adverse event, with similar numbers in the 2 groups. For 22 $(22 \%)$ participants the event was classified as serious but none led to death. This finding is in line with other trials; the Titre-2 trial, which recruited 2000 participants, albeit with a higher proportion of high-risk participants, reported an SAE rate of $35 \% .^{29}$

The study has strengths and limitations. Strengths include the inclusive eligibility criteria, with few patients referred for isolated CABG or AVR surgery being ineligible; avoidance of bias through concealed allocation, successful blinding of participants, and the health care personnel providing care; and use of an objective primary outcome. The blood samples were analyzed in a single hospital laboratory, thereby avoiding interlaboratory variability, and laboratory personnel conducting the analyses were blinded to the group allocation.

With respect to limitations, the study was carried out in a single center with a single surgeon and the study sample was small. During recruitment more patients were referred for CABG than for AVR, which resulted in proportionally more participants in the CABG than the AVR stratum, reducing the power of the study to detect differences by surgical stratum. Similarly, the study was underpowered to detect differences in outcome between patients with and without diabetes. There were some protocol deviations, including 1 participant allocated to intralipid who had propofol supplementation and 6 participants who received neither intervention; these deviations may have reduced the differences between the groups.

Propofol is a general anesthetic widely used for the induction and maintenance of anesthesia during cardiac surgery. ${ }^{15}$ Its cardioprotective efficacy when used as an anesthetic agent is inferior to standard volatile inhalational anesthetics as shown in patients ${ }^{30}$ and in experimental models. ${ }^{31}$ However, propofol is cardioprotective when used at a relatively high maintenance dose in patients undergoing $\mathrm{CABG}$ using $\mathrm{CPB} .{ }^{32} \mathrm{~A}$ high dose of propofol after isoflurane preconditioning also appears to confer greater protection than isoflurane alone. ${ }^{33}$ The link between propofol anesthesia and cardioprotection remains controversial; recent research suggests that propofol anesthesia reduces the cardioprotection induced by remote ischemic preconditioning. ${ }^{34,35}$

The concentration of propofol used in the study was relatively low given that propofol supplementation of cardioplegia had not been investigated previously and the desire to minimize any risk to participants. Substantially higher cardioplegia supplementation is possible without exceeding the systemic propofol concentration that is frequently experienced during induction and maintenance of general anesthesia with propofol. We consider the safety findings from this trial reassuring and further study is warranted to investigate this promising intervention. It should include a range of supplementation levels extending to a higher level than used in our trial and test for a dose-response relationship.

\section{CONCLUSIONS}

Our study results suggest that propofol supplementation protects the heart against ischemic reperfusion injury and that its influence on early clinical outcomes may differ between CABG and AVR surgery. A further study, using a range of supplementation levels to explore dose-response relationships, is the next step.

\section{Conflict of Interest Statement}

Dr Suleiman reports grants from NIHR, during the conduct of the study. Dr Reeves reports grants from the National Institute for Health Research for the conduct of the study. All other authors have nothing to disclose with regard to commercial support.

\footnotetext{
The authors thank Hua Lin for performing laboratory analyses, the research nurse team led by Emma Hopkins, for patient recruitment and data collection, and Sue Plummer for performing data entry duties.
} 


\section{References}

1. Chambers DJ, Fallouh HB. Cardioplegia and cardiac surgery: pharmacological arrest and cardioprotection during global ischemia and reperfusion. Pharmacol Ther. 2010;127:41-52.

2. Vinten-Johansen J, Thourani VH. Myocardial protection: an overview. J Extra Corpor Technol. 2000;32:38-48.

3. Murphy E, Steenbergen C. Ion transport and energetics during cell death and protection. Physiology (Bethesda). 2008;23:115-23.

4. Tritto FP, Inserte J, Garcia-Dorado D, Ruiz-Meana M, Soler-Soler J. Sodium/ hydrogen exchanger inhibition reduces myocardial reperfusion edema after normothermic cardioplegia. J Thorac Cardiovasc Surg. 1998;115:709-15.

5. Garcia-Dorado D, Oliveras J. Myocardial oedema: a preventable cause of reperfusion injury? Cardiovasc Res. 1993;27:1555-63.

6. Ruiz-Meana M, Garcia-Dorado D, Gonzalez MA, Barrabes JA, Soler-Soler J. Effect of osmotic stress on sarcolemmal integrity of isolated cardiomyocytes following transient metabolic inhibition. Cardiovasc Res. 1995;30:64-9.

7. Halestrap AP, Pasdois P. The role of the mitochondrial permeability transition pore in heart disease. Biochim Biophys Acta. 2009;1787:1402-15.

8. Chen Q, Camara AK, Stowe DF, Hoppel CL, Lesnefsky EJ. Modulation of electron transport protects cardiac mitochondria and decreases myocardial injury during ischemia and reperfusion. Am J Physiol Cell Physiol. 2007;292:C137-47.

9. Halestrap AP. Mitochondria and reperfusion injury of the heart-a holey death but not beyond salvation. J Bioenerg Biomembr. 2009;41:113-21.

10. Dhalla NS, Temsah RM, Netticadan T. Role of oxidative stress in cardiovascular diseases. J Hypertens. 2000;18:655-73.

11. Halestrap AP. A pore way to die: the role of mitochondria in reperfusion injury and cardioprotection. Biochem Soc Trans. 2010;38:841-60.

12. Suleiman MS, Zacharowski K, Angelini GD. Inflammatory response and cardioprotection during open-heart surgery: the importance of anaesthetics. Br J Pharmacol. 2008;153:21-33.

13. Yang W, Li H, Luo H, Luo W. Inhibition of semicarbazide-sensitive amine oxidase attenuates myocardial ischemia-reperfusion injury in an in vivo rat model. Life Sci. 2011;88:302-6.

14. Suleiman MS, Halestrap AP, Griffiths EJ. Mitochondria: a target for myocardial protection. Pharmacol Ther. 2001;89:29-46.

15. Bovill JG. Intravenous anesthesia for the patient with left ventricular dysfunction. Semin Cardiothorac Vasc Anesth. 2006;10:43-8.

16. Kamada N, Kanaya N, Hirata N, Kimura S, Namiki A. Cardioprotective effects of propofol in isolated ischemia-reperfused guinea pig hearts: role of KATP channels and GSK-3beta. Can J Anaesth. 2008;55:595-605.

17. Xia Z, Godin DV, Chang TK, Ansley DM. Dose-dependent protection of cardiac function by propofol during ischemia and early reperfusion in rats: effects on 15F2t-isoprostane formation. Can J Physiol Pharmacol. 2003;81:14-21.

18. Lin C, Sui H, Gu J, Yang X, Deng L, Li W, et al. Effect and mechanism of propofol on myocardial ischemia reperfusion injury in type 2 diabetic rats. Microvasc Res. 2013;90:162-8.

19. King N, Al Shaama M, Suleiman MS. Propofol improves recovery of the isolated working hypertrophic heart from ischaemia-reperfusion. Pflugers Arch. 2012; 464:513-22.

20. Javadov SA, Lim KH, Kerr PM, Suleiman MS, Angelini GD, Halestrap AP. Protection of hearts from reperfusion injury by propofol is associated with inhibition of the mitochondrial permeability transition. Cardiovasc Res. 2000;45:360-9.

21. Kobayashi I, Kokita N, Namiki A. Propofol attenuates ischaemia-reperfusion injury in the rat heart in vivo. Eur J Anaesthesiol. 2008;25:144-51.
22. Lim KH, Halestrap AP, Angelini GD, Suleiman MS. Propofol is cardioprotective in a clinically relevant model of normothermic blood cardioplegic arrest and cardiopulmonary bypass. Exp Biol Med (Maywood). 2005; 230:413-20.

23. Plummer ZE, Baos S, Rogers CA, Suleiman MS, Bryan AJ, Angelini GD, et al The effects of propofol cardioplegia on blood and myocardial biomarkers of stress and injury in patients with isolated coronary artery bypass grafting or aortic valve replacement using cardiopulmonary bypass: protocol for a single-center randomized controlled trial. JMIR Res Protoc. 2014;3:e35.

24. Caputo M, Ascione R, Angelini GD, Suleiman MS, Bryan AJ. The end of the cold era: from intermittent cold to intermittent warm blood cardioplegia. Eur J Cardiothorac Surg. 1998;14:467-75.

25. Ascione R, Caputo M, Gomes WJ, Lotto AA, Bryan AJ, Angelini GD, et al Myocardial injury in hypertrophic hearts of patients undergoing aortic valve surgery using cold or warm blood cardioplegia. Eur J Cardiothorac Surg. 2002;21:440-6.

26. Soraas CL, Friis C, Engebretsen KV, Sandvik L, Kjeldsen SE, Tonnessen T. Troponin $\mathrm{T}$ is a better predictor than creatine kinase-MB of long-term mortality after coronary artery bypass graft surgery. Am Heart J. 2012;164:779-85.

27. Mohammed AA, Agnihotri AK, van Kimmenade RR, Martinez-Rumayor A, Green SM, Quiroz R, et al. Prospective, comprehensive assessment of cardiac troponin $\mathrm{T}$ testing after coronary artery bypass graft surgery. Circulation. 2009; 120:843-50.

28. Rosner MH, Okusa MD. Acute kidney injury associated with cardiac surgery Clin J Am Soc Nephrol. 2006;1:19-32.

29. Murphy GJ, Pike K, Rogers CA, Wordsworth S, Stokes EA, Angelini GD, et al Liberal or restrictive transfusion after cardiac surgery. N Engl J Med. 2015;372: 997-1008.

30. Bein B, Renner J, Caliebe D, Scholz J, Paris A, Fraund S, et al. Sevoflurane but not propofol preserves myocardial function during minimally invasive direct coronary artery bypass surgery. Anesth Analg. 2005;100: 610-6.

31. Andrews DT, Royse AG, Royse CF. Functional comparison of anaesthetic agents during myocardial ischaemia-reperfusion using pressure-volume loops. $\mathrm{Br} \mathrm{J}$ Anaesth. 2009;103:654-64.

32. Xia Z, Huang Z, Ansley DM. Large-dose propofol during cardiopulmonary bypass decreases biochemical markers of myocardial injury in coronary surgery patients: a comparison with isoflurane. Anesth Analg. 2006;103: 527-32.

33. Huang Z, Zhong X, Irwin MG, Ji S, Wong GT, Liu Y, et al. Synergy of isoflurane preconditioning and propofol postconditioning reduces myocardial reperfusion injury in patients. Clin Sci (London). 2011;121:57-69.

34. Kottenberg E, Thielmann M, Bergmann L, Heine T, Jakob H, Heusch G, et al Protection by remote ischemic preconditioning during coronary artery bypass graft surgery with isoflurane but not propofol - a clinical trial. Acta Anaesthesiol Scand. 2012;56:30-8.

35. Kottenberg E, Musiolik J, Thielmann M, Jakob H, Peters J, Heusch G. Interference of propofol with signal transducer and activator of transcription 5 activation and cardioprotection by remote ischemic preconditioning during coronary artery bypass grafting. J Thorac Cardiovasc Surg. 2014;147:376-82.

Key Words: cardioplegia, cardiopulmonary bypass, CABG, AVR, propofol 


\section{SUPPLEMENTAL METHODS}

\section{Cardioplegia Composition and Delivery}

Calafiore warm blood cardioplegia for coronary artery

bypass grafting (CABG). Potassium chloride (15\%) $2 \mathrm{mmol}$ potassium ion/mL, magnesium sulphate $(50 \%) 2 \mathrm{mmol}$ magnesium ion/ $\mathrm{mL}$, mixed in a potassium ion:magnesium ion $4: 1$ ratio.

A $60-\mathrm{mL}$ syringe is prepared with $20 \mathrm{~mL}$ potassium chloride and $5 \mathrm{~mL}$ magnesium sulfate and is loaded into a syringe driver. A roller pump draws oxygenated blood from the oxygenator and the potassium/magnesium ion mixture is added by syringe pump downstream. Intermittent antegrade delivery is used according to local protocol.

Cold blood cardioplegia for aortic valve replacement (AVR). One liter Harefield Hospital Formulation (Ivex Pharmaceuticals) containing: $8.6 \mathrm{~g}$ sodium chloride British Pharmacopoeia (BP), $6.252 \mathrm{~g}$ potassium chloride BP, $16.262 \mathrm{~g}$ magnesium chloride BP, 330 $\mathrm{mg}$ calcium chloride $\mathrm{BP}$, and $1364 \mathrm{mg}$ procaine hydrochloride BP.

In water for injections, also: $147 \mathrm{mmol}$ sodium, $84 \mathrm{mmol}$ potassium, 80 mmol magnesium, $2 \mathrm{mmol}$ calcium, $3 \mathrm{mmol}$ procaine, and $400 \mathrm{mmol}$ chloride.

A 500-mL prebagged solution was used. A roller pump drew oxygenated blood from the oxygenator and the cardioplegia solution was added in a 4:1 blood:cardioplegia ratio. Cold cardioplegia was given at a temperature of approximately $4{ }^{\circ} \mathrm{C}$ and by either antegrade or retrograde delivery (or a mixture of both) according to local protocol.

\section{Anesthesia}

Premed. 10-30 mg Temazepam 1-2 $\mathrm{h}$ before induction.

Induction. Midazolam; 5-10 $\mu \mathrm{g} / \mathrm{kg}$ fentanyl; with or without propofol up to $1 \mathrm{mg} / \mathrm{kg}$, muscle relaxation as per standard practice.

Maintenance before cardiopulmonary bypass (CPB). Isoflurane plus boluses of fentanyl as indicated (up to max $20 \mu \mathrm{g} / \mathrm{kg}$ ).

Maintenance on CPB. Propofol target controlled infusion (TCI): initial target $3 \mu \mathrm{g} / \mathrm{mL}$ (set according to the estimated ideal body weight) titrated up/down to response.

Maintenance after CPB. Propofol TCI, converted to propofol infusion (not target controlled) for transfer to cardiac intensive care.

\section{Statistical Methods-Further Details}

When analyzing continuous variables measured at baseline, the baseline and posttreatment values were modeled jointly to avoid having to exclude or impute cases with missing baseline measures. For the analysis of myocardial troponin $\mathrm{T}$ (cTnT), a significant proportion of participants had preoperative cTnT concentrations below the limit of detection $(14 \mathrm{ng} / \mathrm{L})$, so the baseline cTnT was grouped into not detectable, detectable but below the median detectable value, or above the median detectable value. This categorical variable was then fitted as a covariate in the analysis model. EQ-5D utility scores were dichotomized into "perfect health" ( (score $<1)$ and compared using logistic regression; responses of almost $40 \%$ of participants at 3 months corresponded to a utility of 1 , and models analyzing utility as a continuously scaled variable did not fit the data well.

There were 4 sensitivity analyses specified in the statistical analysis plan. Two were for the primary outcome. One excluded participants who did not receive either intervention and the other grouped participants by the treatment received (as opposed to treatment allocated). The other 2 were for health status, in which one assumed missing responses to questions in the Minnesota Living with Heart Failure Questionnaire represent the worst possible outcome (the primary analysis assumes missing responses represent no limitation on ability to complete tasks) and the other included baseline data for the 1 participant who completed the preoperative questionnaires retrospectively after their operation.

\section{Subgroup Analyses}

A subgroup analysis was performed to investigate whether the effect of propofol on troponin $\mathrm{T}$ release differed by diabetic status. The results of the analysis are shown in Figure E1. There was no statistically significant difference in the effect of troponin between diabetic and nondiabetic participants (interaction term $P$ value $=.54$ ); however, the power to test for an interaction is low. The estimates of the treatment effect in the 2 subgroups are consistent with the overall analysis. The diabetic cohort is small $(\mathrm{n}=$ $21)$ and the confidence interval is wide.

\section{Sensitivity Analyses}

Primary outcome, Troponin T. The results of both sensitivity analyses were consistent with the main analyses; troponin $\mathrm{T}$ levels were lower in the propofol group, and of borderline statistical significance (Figure E2).

Secondary outcomes. These sensitivity analyses did not change the study conclusions (Figure E4). For the EQ-5D utility score, the $P$ value for the test of interaction between allocation and operation type was .068. 


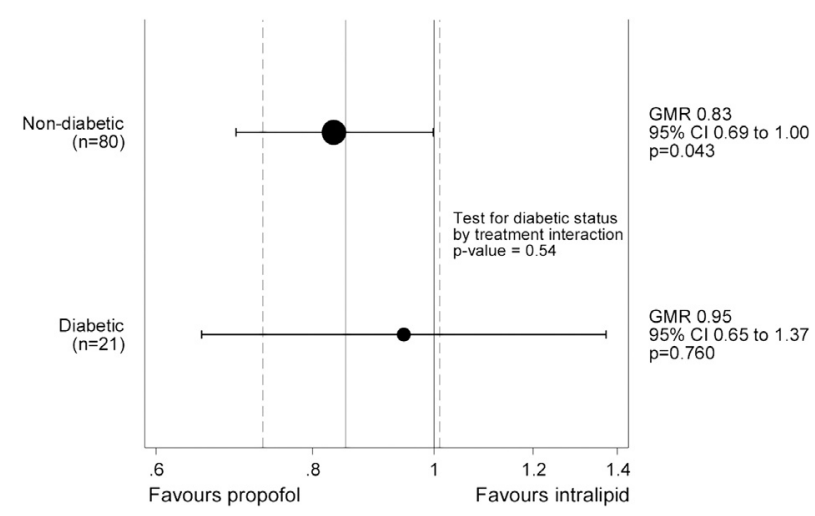

FIGURE E1. Effect of propofol on cardiac troponin T release by diabetes status. GMR, Geometric mean ratio; $C I$, confidence interval.

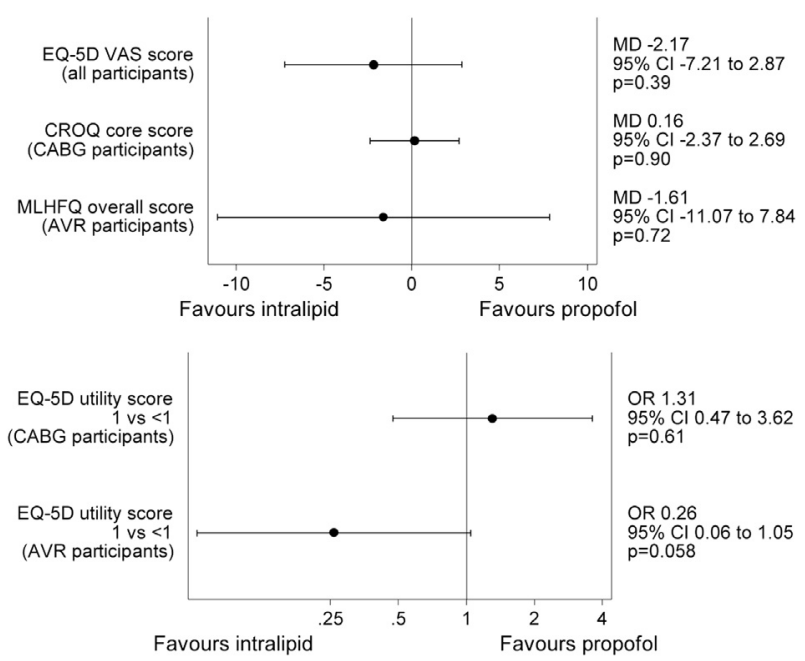

FIGURE E3. Quality of life scores at 3 months. EQ-5D, EQ-5D health questionnaire; VAS, visual analog scale; $C R O Q$, Coronary Revascularisation Outcome Questionnaire; $C A B G$, coronary artery bypass graft; $M L H F Q$, Minnesota Living with Heart Failure Questionnaire; $M D$, mean difference; $O R$, odds ratio; $A V R$, aortic valve replacement; $C I$, confidence interval.

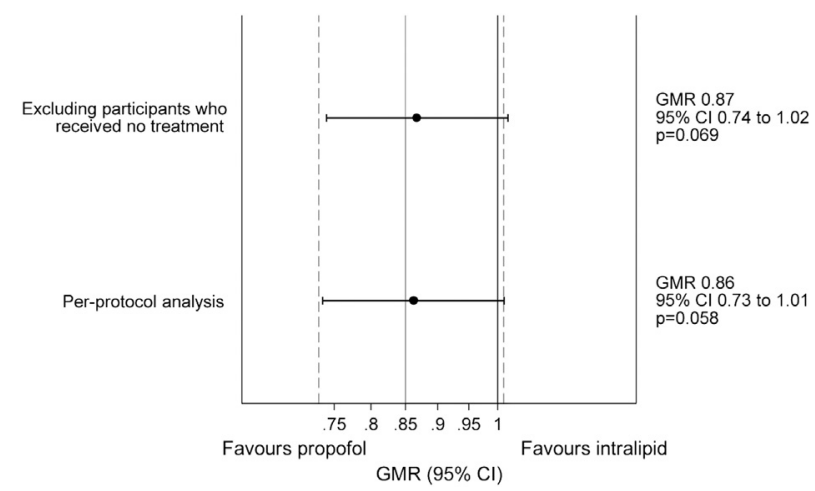

FIGURE E2. Effect of propofol on troponin $\mathrm{T}$ release: sensitivity analyses. GMR, Geometric mean ratio; $C I$, confidence interval.
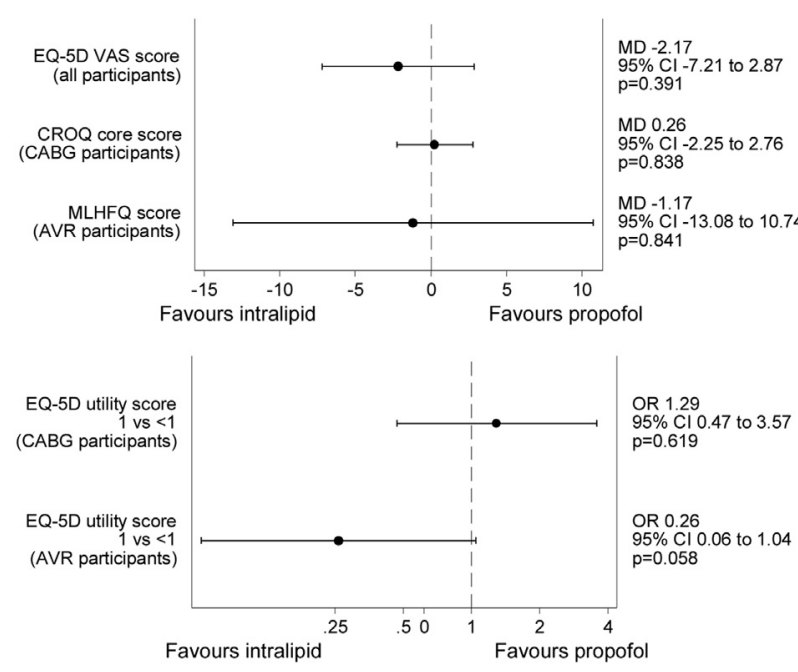

FIGURE E4. Effect of propofol on quality-of-life scores: sensitivity analyses. EQ-5D, EQ-5D health questionnaire; VAS, visual analog scale; $C R O Q$, Coronary Revascularisation Outcome Questionnaire; $C A B G$, coronary artery bypass graft; $M L H F Q$, Minnesota Living with Heart Failure Questionnaire; $M D$, mean difference; $O R$, odds ratio; $A V R$, aortic valve replacement; $C I$, confidence interval. 
TABLE E1. Protocol deviations

\begin{tabular}{|c|c|c|c|c|c|c|}
\hline \multirow[b]{2}{*}{ Protocol deviation } & \multicolumn{2}{|c|}{ Randomized to propofol $(n=51)$} & \multicolumn{2}{|c|}{ Randomized to intralipid $(n=50)$} & \multicolumn{2}{|c|}{ Overall $(\mathbf{n}=101)$} \\
\hline & $\mathbf{n}$ & $\%$ & $\mathbf{n}$ & $\%$ & $\mathbf{n}$ & $\%$ \\
\hline $\begin{array}{l}\text { Participant received the alternative treatment to that } \\
\text { allocated }\end{array}$ & $0 / 51$ & 0 & $1 / 50$ & 2 & $1 / 101$ & 1 \\
\hline Did not meet the eligibility criteria but was treated & $0 / 51$ & 0 & $2 / 50$ & 4 & $2 / 101$ & 2 \\
\hline Deviated from the trial protocol for induction & $1 / 51$ & 2 & $1 / 50$ & 2 & $2 / 101$ & 2 \\
\hline $\begin{array}{l}\text { Deviated from the trial protocol for maintenance on } \\
\text { cardiopulmonary bypass }\end{array}$ & $4 / 51$ & 8 & $6 / 50$ & 12 & $10 / 101$ & 10 \\
\hline Discontinuation of study treatment & $4 / 51$ & 8 & $2 / 50$ & 4 & $6 / 101$ & 6 \\
\hline Aortic valve repair participants only & \multicolumn{2}{|c|}{$(\mathbf{n}=\mathbf{2 0})$} & \multicolumn{2}{|c|}{$(\mathbf{n}=\mathbf{2 0})$} & \multicolumn{2}{|c|}{$(n=40)$} \\
\hline $\begin{array}{l}7.5 \mathrm{~mL} \text { cardioplegia not replaced with } 7.5 \mathrm{~mL} \text { diluted } \\
\text { intralipid/propofol solution from the study } \\
\text { syringe during cold blood cardioplegia }\end{array}$ & $0 / 20$ & 0 & $1 / 19$ & 5 & $1 / 39$ & 3 \\
\hline
\end{tabular}

Missing data (numbers for propofol and intralipid groups respectively): $7.5 \mathrm{~mL}$ cardioplegia not replace with $7.5 \mathrm{~mL}$ diluted intralipid/propofol solution from the study syringe during cold blood cardioplegia: $1(0,1)$.

TABLE E2. Details of protocol deviations (where available)

\begin{tabular}{|c|c|}
\hline Type of deviation & Further details \\
\hline \multicolumn{2}{|l|}{ Randomized to propofol } \\
\hline Deviated from the trial protocol for induction & No misazolam given because had lorazepam premed \\
\hline Deviated from the trial protocol for maintenance on $\mathrm{CPB}$ & Propofol TCI titrated to $2 \mu \mathrm{g} / \mathrm{mL}$ due to low blood pressure \\
\hline Deviated from the trial protocol for maintenance on $\mathrm{CPB}$ & Propofol TCI titrated to $2 \mu \mathrm{g} / \mathrm{mL}$ due to hypotension \\
\hline Deviated from the trial protocol for maintenance on $\mathrm{CPB}$ & Propofol TCI titrated to $2-3 \mu \mathrm{g} / \mathrm{mL}$ \\
\hline Deviated from the trial protocol for maintenance on $\mathrm{CPB}$ & Propofol TCI titrated to $2 \mu \mathrm{g} / \mathrm{mL}$ to maintain blood pressure \\
\hline Discontinuation of study treatment & Surgeon changed postrandomization (operation performed off pump) \\
\hline Discontinuation of study treatment & Surgeon changed postrandomization \\
\hline Discontinuation of study treatment & $\begin{array}{l}\text { Participant found to be ineligible during surgery (poor left ventricular } \\
\text { function) - withdrawn from treatment }\end{array}$ \\
\hline Discontinuation of study treatment & Temperature breach, drugs not suitable \\
\hline \multicolumn{2}{|l|}{ Randomized to intralipid } \\
\hline Participant received the alternative treatment to that allocated & Theatre slots switched, paperwork for other participant used in error \\
\hline Did not meet the eligibility criteria but was treated & Had AVR with or without ablation therefore not isolated AVR \\
\hline Did not meet the eligibility criteria but was treated & $\begin{array}{l}\text { Scheduled for isolated AVR, but surgeon decided to also perform CABG } \\
\text { during procedure }\end{array}$ \\
\hline Deviated from the trial protocol for induction & $\begin{array}{l}>1 \mathrm{mg} / \mathrm{kg} \text { propofol given - high blood pressure despite the above }-100 \mathrm{mg} \\
\text { total bolus }\end{array}$ \\
\hline Deviated from the trial protocol for maintenance on $\mathrm{CPB}$ & $\begin{array}{l}\text { Propofol TCI titrated to } 2 \mu \mathrm{g} / \mathrm{mL} \text { due to hemodynamic response (ie, blood } \\
\text { pressure down) }\end{array}$ \\
\hline Deviated from the trial protocol for maintenance on $\mathrm{CPB}$ & Propofol TCI titrated to $2 \mu \mathrm{g} / \mathrm{mL}$ as clinically sufficient \\
\hline Deviated from the trial protocol for maintenance on $\mathrm{CPB}$ & Propofol TCI titrated down to $2 \mu \mathrm{g} / \mathrm{mL}$ due to low blood pressure \\
\hline Deviated from the trial protocol for maintenance on $\mathrm{CPB}$ & $\begin{array}{l}\text { Propofol TCI titrated to } 2.5 \mu \mathrm{g} / \mathrm{mL} \text { - low blood pressure therefore higher } \\
\text { dose not given }\end{array}$ \\
\hline Deviated from the trial protocol for maintenance on $\mathrm{CPB}$ & Propofol TCI titrated to $2 \mu \mathrm{g} / \mathrm{mL}$ due to hypotension \\
\hline Deviated from the trial protocol for maintenance on $\mathrm{CPB}$ & Propofol TCI titrated to $>3 \mu \mathrm{g} / \mathrm{mL}$ due to hypertension on CPB \\
\hline Discontinuation of study treatment & Swapped theatre, drugs not transferred \\
\hline Discontinuation of study treatment & $\begin{array}{l}\text { Participant found to be ineligible during surgery (poor left ventricular } \\
\text { function) - withdrawn from treatment }\end{array}$ \\
\hline $\begin{array}{l}7.5 \mathrm{~mL} \text { cardioplegia not replaced with } 7.5 \mathrm{~mL} \text { diluted intralipid/propofol } \\
\text { solution from the study syringe during cold blood cardioplegia }\end{array}$ & $25 \mathrm{~mL}$ intralipid solution \\
\hline
\end{tabular}


TABLE E3. Additional patient demographic information and past history

Characteristic

Randomized to propofol $(n=51) \quad$ Randomized to intralipid $(n=50) \quad$ Overall $(n=101)$

Cardiac history

New York Heart Association functional class

$14(27)$

$10(20)$

24 (24)

20 (39)

$26(52)$

46 (46)

III

$16(31)$

14 (28)

$30(30)$

IV

1 (2)

$0(0)$

1 (1)

Canadian Cardiovascular Society class

Asymptomatic

11 (22)

$16(32)$

27 (27)

8 (16)

6 (12)

14 (14)

II

20 (39)

17 (34)

37 (37)

III

11 (22)

8 (16)

19 (19)

IV

1 (2)

3 (6)

4 (4)

10 (20)

13 (26)

23 (23)

Myocardial infarction within past $90 \mathrm{~d}$

$3(33)$

7 (58)

$10(48)$

Heart rhythm

Sinus 44 (88)

Atrial fibrillation/flutter

Noncardiac history

Hypercholesterolemia

37 (73)

Hypothyroidism

$4(8)$

Preoperative tests

Hemoglobin (g/dL)

Platelets $\left(\times 10^{9} / \mathrm{L}\right)$

Preoperative medications

Aspirin

Time aspirin stopped before surgery (d)

Clopidogrel

Time clopidogrel stopped before surgery (d)

Warfarin

Time warfarin stopped before surgery (d)

Heparin/clexane

Time heparin/clexane stopped before surgery (d)

Beta blockers

$13.7 \pm 1.7$

$221.2 \pm 53.6$

47 (94)

3 (6)

$91(91)$

9 (9)

39 (78)

$76(75)$

5 (10)

9 (9)

$13.5 \pm 1.7$

$13.6 \pm 1.7$

$232.1 \pm 63.9$

$226.6 \pm 58.9$

$\begin{array}{ccc}35(69) & 35(70) & 70(69) \\ 1.0(1.0-2.0) & 1.0(1.0-1.0) & 1.0(1.0-2.0) \\ 16(31) & 11(22) & 27(27) \\ 6.0(3.0-7.0) & 8.0(3.0-9.0) & 6.5(3.0-8.0) \\ 4(8) & 3(6) & 7(7) \\ 4.5(4.0-5.5) & 5.0(4.0-5.0) & 5.0(4.0-5.0) \\ 1(2) & 2(4) & 3(3) \\ 2.0(2.0-2.0) & 2.0(2.0-2.0) & 2.0(2.0-2.0) \\ 28(55) & 24(48) & 52(51) \\ 16(31) & 11(22) & 27(27) \\ 7(14) & 9(18) & 16(16) \\ 2(4) & 2(4) & 4(4) \\ 41(80) & 39(78) & 80(79) \\ 27(53) & 22(44) & 49(49) \\ 5(10) & 1(2) & 6(6) \\ 12(24) & 8(16) & 20(20) \\ 3(6) & 3(6) & 6(6) \\ 1(2) & 1(2) & 2(2)\end{array}$

Other lipid-lowering agents*

Statins

Angiotensin-converting enzyme inhibitors

Angiotensin II blockers

$1(2)$

Diuretics

Digoxin

Antiarrhythmic

Values are presented as $\mathrm{n}(\%)$, median (interquartile range), or mean \pm standard deviation. Missing data (numbers for propofol and intralipid groups respectively): myocardial infarction within past 90 days: $2(1,1)$, heart rhythm: $1(1,0)$, time clopidogrel stopped before surgery: $1(1,0)$, time heparin/clexane stopped before surgery: $1(0,1)$. $*$ Other lipidlowering agents used in propofol group for 2 participants ("ezetimibe" and " $5 \mathrm{mg}$ bioprolol, $40 \mathrm{mg}$ simvastatin, $400 \mathrm{mg}$ nitromin spray, $10 \mathrm{mg}$ ramapril"). Other lipid-lowering agents used in intralipid group for 2 participants ("ezetimibe" and "160 mg fenofibrate"). 
TABLE E4. Participant demographic characteristics and past history by surgical stratum

\begin{tabular}{|c|c|c|c|c|c|c|}
\hline \multirow[b]{2}{*}{ Characteristic } & \multicolumn{3}{|c|}{ Corornary artery bypass grafting } & \multicolumn{3}{|c|}{ Aortic valve replacement } \\
\hline & $\begin{array}{l}\text { Randomized } \\
\text { to propofol } \\
(\mathbf{n}=\mathbf{3 1})\end{array}$ & $\begin{array}{l}\text { Randomized } \\
\text { to intralipid } \\
\quad(n=30)\end{array}$ & $\begin{array}{l}\text { Overall } \\
(\mathrm{n}=61)\end{array}$ & $\begin{array}{l}\text { Randomized } \\
\text { to propofol } \\
(\mathbf{n}=\mathbf{2 0})\end{array}$ & $\begin{array}{l}\text { Randomized } \\
\text { to intralipid } \\
\quad(n=20)\end{array}$ & $\begin{array}{l}\text { Overall } \\
(n=40)\end{array}$ \\
\hline Age (y) & $67.4(63.7-72.1)$ & $69.8(63.8-76.4)$ & $67.9(63.8-73.7)$ & $65.0(61.8-70.4)$ & $70.7(66.1-76.5)$ & $67.5(64.3-74.3)$ \\
\hline Male & $28(90)$ & $26(87)$ & $54(89)$ & $13(65)$ & $10(50)$ & $23(58)$ \\
\hline Body mass index & $29.6 \pm 5.4$ & $27.1 \pm 4.2$ & $28.4 \pm 5.0$ & $28.9 \pm 6.1$ & $27.2 \pm 3.2$ & $28.1 \pm 4.9$ \\
\hline Diabetic & $9(29)$ & $9(30)$ & $18(30)$ & $2(10)$ & $1(5)$ & $3(8)$ \\
\hline $\begin{array}{l}\text { Estimated glomerular filtration } \\
\text { rate* }\left(\mathrm{mL} / \mathrm{min} / 1.73 \mathrm{~m}^{2}\right)\end{array}$ & $74.4 \pm 19.9$ & $75.3 \pm 13.0$ & $74.9 \pm 16.7$ & $62.8 \pm 18.5$ & $67.5 \pm 16.5$ & $65.1 \pm 17.4$ \\
\hline \multicolumn{7}{|l|}{ Cardiac history } \\
\hline $\begin{array}{l}\text { European System for Cardiac } \\
\text { Operative Risk Evaluation score }\end{array}$ & $3(2.0-4.0)$ & $4(2.0-5.0)$ & $3(2.0-5.0)$ & $4(3.5-5.5)$ & $6(5.0-6.5)$ & $5(4.0-6.0)$ \\
\hline \multicolumn{7}{|l|}{ New York Heart Association functional class } \\
\hline I/asymptomatic & $8(26)$ & $7(23)$ & $15(25)$ & $6(30)$ & $3(15)$ & $9(23)$ \\
\hline II & $14(45)$ & $17(57)$ & $31(51)$ & $6(30)$ & $9(45)$ & $15(38)$ \\
\hline III & $8(26)$ & $6(20)$ & $14(23)$ & $8(40)$ & $8(40)$ & $16(40)$ \\
\hline IV & $1(3)$ & $0(0)$ & $1(2)$ & $0(0)$ & $0(0)$ & $0(0)$ \\
\hline \multicolumn{7}{|l|}{ Canadian Cardiovascular Society class } \\
\hline Asymptomatic & $2(6)$ & $2(7)$ & $4(7)$ & $9(45)$ & $14(70)$ & $23(58)$ \\
\hline I & $5(16)$ & $6(20)$ & $11(18)$ & $3(15)$ & $0(0)$ & $3(8)$ \\
\hline II & $15(48)$ & $12(40)$ & $27(44)$ & $5(25)$ & $5(25)$ & $10(25)$ \\
\hline III & $8(26)$ & $7(23)$ & $15(25)$ & $3(15)$ & $1(5)$ & $4(10)$ \\
\hline IV & $1(3)$ & $3(10)$ & $4(7)$ & $0(0)$ & $0(0)$ & $0(0)$ \\
\hline Previous myocardial infarction & $10(32)$ & $13(43)$ & $23(38)$ & $0(0)$ & $0(0)$ & $0(0)$ \\
\hline Myocardial infarction within last $90 \mathrm{~d}$ & $3(33)$ & $7(58)$ & $10(48)$ & $0(0)$ & $0(0)$ & $0(0)$ \\
\hline \multicolumn{7}{|l|}{ Heart rhythm } \\
\hline Sinus & $28(90)$ & $30(100)$ & $58(95)$ & $16(84)$ & $17(85)$ & $33(85)$ \\
\hline Atrial fibrillation/flutter & $3(10)$ & $0(0)$ & $3(5)$ & $3(16)$ & $3(15)$ & $6(15)$ \\
\hline \multicolumn{7}{|l|}{ Coronary disease (No. of vessels) $\dagger$} \\
\hline None & 0 & 0 & 0 & $20(100)$ & $19(95)$ & $39(98)$ \\
\hline Single & $1(3)$ & $1(3)$ & $2(3)$ & $0(0)$ & $1(5)$ & $1(3)$ \\
\hline Double & $6(19)$ & $12(40)$ & $18(30)$ & $0(0)$ & $0(0)$ & $0(0)$ \\
\hline Triple & $24(77)$ & $17(57)$ & $41(67)$ & $0(0)$ & $0(0)$ & $0(0)$ \\
\hline$>50 \%$ disease in left main stem & $9(29)$ & $5(17)$ & $14(23)$ & $0(0)$ & $0(0)$ & $0(0)$ \\
\hline \multicolumn{7}{|l|}{ Noncardiac history } \\
\hline \multicolumn{7}{|l|}{ Smoking status } \\
\hline Smoker & $5(16)$ & $4(13)$ & $9(15)$ & $0(0)$ & $1(5)$ & $1(3)$ \\
\hline Nonsmoker & $9(29)$ & $12(40)$ & $21(34)$ & $8(40)$ & $12(60)$ & $20(50)$ \\
\hline Exsmoker $>1$ mo & $17(55)$ & $14(47)$ & $31(51)$ & $12(60)$ & $7(35)$ & $19(48)$ \\
\hline Family history & $14(45)$ & $21(70)$ & $35(57)$ & $10(50)$ & $10(50)$ & $20(50)$ \\
\hline Hypertension requiring treatment & $29(94)$ & $22(73)$ & $51(84)$ & $15(75)$ & $13(65)$ & $28(70)$ \\
\hline Hypercholesterolemia & $25(81)$ & $29(97)$ & $54(89)$ & $12(60)$ & $10(50)$ & $22(55)$ \\
\hline Hypothyroidism & $2(6)$ & $3(10)$ & $5(8)$ & $2(10)$ & $2(10)$ & $4(10)$ \\
\hline Stroke or transient ischemic attacks & $2(6)$ & $2(7)$ & $4(7)$ & $0(0)$ & $2(10)$ & $2(5)$ \\
\hline Elective procedure & $27(87)$ & $27(90)$ & $54(89)$ & $20(100)$ & $19(95)$ & $39(98)$ \\
\hline \multicolumn{7}{|l|}{ Preoperative tests } \\
\hline Hemoglobin (g/dL) & $13.8 \pm 1.9$ & $13.6 \pm 1.8$ & $13.7 \pm 1.9$ & $13.5 \pm 1.5$ & $13.4 \pm 1.6$ & $13.5 \pm 1.5$ \\
\hline Platelets $\left(\times 10^{9} / \mathrm{L}\right)$ & $218.5 \pm 43.4$ & $226.6 \pm 59.1$ & $222.4 \pm 51.4$ & $225.4 \pm 67.5$ & $240.3 \pm 71.3$ & $232.8 \pm 68.9$ \\
\hline \multicolumn{7}{|l|}{ Preoperative medications } \\
\hline Aspirin & $28(90)$ & $29(97)$ & $57(93)$ & $7(35)$ & $6(30)$ & $13(33)$ \\
\hline Time aspirin stopped before surgery) (d) & $1.0(1.0-2.0)$ & $1.0(1.0-1.0)$ & $1.0(1.0-2.0)$ & $1.0(1.0-4.0)$ & $1.0(1.0-1.0)$ & $1.0(1.0-1.0)$ \\
\hline Clopidogrel & $15(48)$ & $11(37)$ & $26(43)$ & $1(5)$ & $0(0)$ & $1(3)$ \\
\hline Time clopidogrel stopped before surgery (d) & $6.5(5.0-7.0)$ & $8.0(3.0-9.0)$ & $7.0(5.0-8.0)$ & $1.0(1.0-1.0)$ & & $1.0(1.0-1.0)$ \\
\hline Warfarin & $1(3)$ & $0(0)$ & $1(2)$ & $3(15)$ & $3(15)$ & $6(15)$ \\
\hline Time warfarin stopped before surgery(d) & $6.0(6.0-6.0)$ & & $6.0(6.0-6.0)$ & $4.0(4.0-5.0)$ & $5.0(4.0-5.0)$ & $4.5(4.0-5.0)$ \\
\hline
\end{tabular}




\begin{tabular}{|c|c|c|c|c|c|c|}
\hline \multirow[b]{2}{*}{ Characteristic } & \multicolumn{3}{|c|}{ Corornary artery bypass grafting } & \multicolumn{3}{|c|}{ Aortic valve replacement } \\
\hline & $\begin{array}{c}\text { Randomized } \\
\text { to propofol } \\
(\mathbf{n}=\mathbf{3 1}) \\
\end{array}$ & $\begin{array}{c}\text { Randomized } \\
\text { to intralipid } \\
(\mathbf{n}=\mathbf{3 0}) \\
\end{array}$ & $\begin{array}{c}\text { Overall } \\
(n=61)\end{array}$ & $\begin{array}{c}\text { Randomized } \\
\text { to propofol } \\
(\mathbf{n}=\mathbf{2 0}) \\
\end{array}$ & $\begin{array}{c}\text { Randomized } \\
\text { to intralipid } \\
(\mathbf{n}=\mathbf{2 0})\end{array}$ & $\begin{array}{r}\text { Overall } \\
(\mathrm{n}=\mathbf{4 0})\end{array}$ \\
\hline Heparin/clexane & $1(3)$ & $1(3)$ & $2(3)$ & $0(0)$ & $1(5)$ & $1(3)$ \\
\hline $\begin{array}{l}\text { Time heparin/clexane stopped } \\
\text { before surgery (d) }\end{array}$ & $2.0(2.0-2.0)$ & $2.0(2.0-2.0)$ & $2.0(2.0-2.0)$ & & & \\
\hline Beta blockers & $22(71)$ & $18(60)$ & $40(66)$ & $6(30)$ & $6(30)$ & $12(30)$ \\
\hline Calcium antagonists & $12(39)$ & $8(27)$ & $20(33)$ & $4(20)$ & $3(15)$ & $7(18)$ \\
\hline Oral nitrates & $7(23)$ & $8(27)$ & $15(25)$ & $0(0)$ & $1(5)$ & $1(3)$ \\
\hline Other lipid-lowering agents $\ddagger$ & $1(3)$ & $2(7)$ & $3(5)$ & $1(5)$ & $0(0)$ & $1(3)$ \\
\hline Statins & $29(94)$ & $29(97)$ & $58(95)$ & $12(60)$ & $10(50)$ & $22(55)$ \\
\hline Angiotensin-converting enzyme inhibitors & $15(48)$ & $17(57)$ & $32(52)$ & $12(60)$ & $5(25)$ & $17(43)$ \\
\hline Angiotensin II blockers & $4(13)$ & $0(0)$ & $4(7)$ & $1(5)$ & $1(5)$ & $2(5)$ \\
\hline Diuretics & $5(16)$ & $3(10)$ & $8(13)$ & $7(35)$ & $5(25)$ & $12(30)$ \\
\hline Digoxin & $1(3)$ & $0(0)$ & $1(2)$ & $2(10)$ & $3(15)$ & $5(13)$ \\
\hline Antiarrhythmic & $0(0)$ & $1(3)$ & $1(2)$ & $1(5)$ & $0(0)$ & $1(3)$ \\
\hline
\end{tabular}

Values are presented as median (interquartile range), $\mathrm{n}(\%)$, or mean \pm standard deviation. Missing data (numbers for coronary bypass grafting propofol, coronary bypass grafting intralipid, aortic valve replacement propofol and aortic valve replacement intralipid groups respectively): European System for Cardiac Operative Risk Evaluation: 2 (1, 1, 0, 0), myocardial infarction within past 90 days: $2(1,1,0,0)$, heart rhythm: $1(0,0,1,0)$, time clopidogrel stopped before surgery: $1(1,0,0,0)$, and time heparin/clexane stopped before surgery: $1(0,0,0,1)$. *Baseline creatinine is reported in Table E9. †One participant in the aortic valve replacement intralipid group had aortic valve replacement and coronary bypass graft surgery—-therefore the number of vessels for this participant is single, whereas all other aortic valve replacement participants have "none”. $\ddagger$ Other lipid-lowering agents used in coronary artery bypass grafting propofol group for 1 participant (" $5 \mathrm{mg}$ bioprolol, $40 \mathrm{mg}$ simvastatin, $400 \mathrm{mg}$ nitromin spray, and $10 \mathrm{mg}$ ramapril"). Other lipidlowering agents used in aortic valve replacement propofol group for 1 participant ("ezetimibe"). Other lipid-lowering agents used in coronary artery bypass grafting intralipid group for 2 participants ("ezetimibe" and " $160 \mathrm{mg}$ fenofibrate"). 
TABLE E5. Intraoperative and postoperative details by surgical stratum

\begin{tabular}{|c|c|c|c|c|c|c|}
\hline \multirow[b]{2}{*}{$\begin{array}{c}\text { Intraoperative/postoperative } \\
\text { characteristic }\end{array}$} & \multicolumn{3}{|c|}{ Coronary artery bypass grafting } & \multicolumn{3}{|c|}{ Aortic valve replacement } \\
\hline & $\begin{array}{c}\text { Randomized } \\
\text { to propofol } \\
(\mathbf{n}=\mathbf{3 1})\end{array}$ & $\begin{array}{c}\text { Randomized } \\
\text { to intralipid } \\
\quad(n=30)\end{array}$ & $\begin{array}{l}\text { Overall } \\
(n=61)\end{array}$ & $\begin{array}{c}\text { Randomized } \\
\text { to propofol } \\
(\mathbf{n}=20)\end{array}$ & $\begin{array}{c}\text { Randomized } \\
\text { to intralipid } \\
\quad(n=20)\end{array}$ & $\begin{array}{r}\text { Overall } \\
(n=40)\end{array}$ \\
\hline \multicolumn{7}{|l|}{ Intraoperative details } \\
\hline Operation duration (min) & $190.1 \pm 25.1$ & $193.3 \pm 28.1$ & $191.7 \pm 26.4$ & $192.4 \pm 41.6$ & $185.3 \pm 32.1$ & $188.8 \pm 36.8$ \\
\hline Cumulative crossclamp time $(\mathrm{min})^{*}$ & $42.3 \pm 9.9$ & $43.1 \pm 9.2$ & $42.7 \pm 9.5$ & $71.7 \pm 17.6$ & $68.9 \pm 11.5$ & $70.3 \pm 14.7$ \\
\hline Total bypass time $(\mathrm{min})^{*}$ & $79.4 \pm 17.6$ & $80.6 \pm 17.4$ & $80.0 \pm 17.3$ & $101.3 \pm 21.7$ & $101.1 \pm 14.6$ & $101.2 \pm 18.2$ \\
\hline \multicolumn{7}{|l|}{ Cardioplegia infusion mode* } \\
\hline Antegrade & $30(100)$ & $30(100)$ & $60(100)$ & $5(25)$ & $4(20)$ & $9(23)$ \\
\hline Retrograde and antegrade & $0(0)$ & $0(0)$ & $0(0)$ & $15(75)$ & $16(80)$ & $31(78)$ \\
\hline Intermittent infusion* & $30(100)$ & $30(100)$ & $60(100)$ & $20(100)$ & $20(100)$ & $40(100)$ \\
\hline $\begin{array}{l}\text { Concentration of propofol in blood in } \\
\text { cardioplegia circuit }(\mu \mathrm{g} / \mathrm{mL}) \dagger\end{array}$ & $9.72 \pm 1.32$ & $4.73 \pm 2.01$ & $7.22 \pm 3.03$ & $10.2 \pm 1.43$ & $4.08 \pm 1.42$ & $7.07 \pm 3.41$ \\
\hline \multicolumn{7}{|l|}{$\begin{array}{l}\text { Concentration of systemic (arterial } \\
\text { line) plasma propofol }(\mu \mathrm{g} / \mathrm{mL})\end{array}$} \\
\hline Before crossclamp $\dagger$ & $3.72 \pm 1.32$ & $4.52 \pm 1.31$ & $4.12 \pm 1.36$ & $4.21 \pm 1.43$ & $4.08 \pm 1.42$ & $4.15 \pm 1.41$ \\
\hline During crossclamp $\dagger$ & $4.11 \pm 1.24$ & $4.39 \pm 0.92$ & $4.25 \pm 1.10$ & $4.24 \pm 1.16$ & $4.32 \pm 1.57$ & $4.28 \pm 1.37$ \\
\hline 10 min after crossclamp release $\dagger$ & $3.98 \pm 1.23$ & $4.51 \pm 0.96$ & $4.24 \pm 1.12$ & $4.21 \pm 0.90$ & $4.51 \pm 1.46$ & $4.37 \pm 1.21$ \\
\hline \multicolumn{7}{|l|}{ Blood saving techniques } \\
\hline Tranexamic acid & $31(100)$ & $28(93)$ & $59(97)$ & $16(80)$ & $20(100)$ & $36(90)$ \\
\hline If yes, dose (g) & $2.0(2.0-4.0)$ & $2.0(2.0-2.0)$ & $2.0(2.0-2.7)$ & $2.0(2.0-4.1)$ & $2.0(2.0-4.3)$ & $2.0(2.0-4.1)$ \\
\hline Pump blood given & $28(90)$ & $30(100)$ & $58(95)$ & $17(85)$ & $20(100)$ & $37(93)$ \\
\hline If yes, pump blood washed & $2(7)$ & $1(4)$ & $3(5)$ & $0(0)$ & $0(0)$ & $0(0)$ \\
\hline Inotropic support & $4(13)$ & $2(7)$ & $6(10)$ & $2(10)$ & $1(5)$ & $3(7.5)$ \\
\hline Noradrenaline & $3(10)$ & $0(0)$ & $3(5)$ & $1(5)$ & $1(5)$ & $2(5)$ \\
\hline Dobutamine & $2(6)$ & $1(3)$ & $3(5)$ & $1(5)$ & $0(0)$ & $1(3)$ \\
\hline Dopamine & $0(0)$ & $1(3)$ & $1(2)$ & $0(0)$ & $0(0)$ & $0(0)$ \\
\hline Enoximone & $1(3)$ & $0(0)$ & $1(2)$ & $0(0)$ & $0(0)$ & $0(0)$ \\
\hline Insulin infusion given after bypass & $5(16)$ & $2(7)$ & $7(11)$ & $4(20)$ & $2(10)$ & $6(15)$ \\
\hline Intraoperative vasodilator used & $0(0)$ & $3(10)$ & $3(5)$ & $3(15)$ & $2(10)$ & $5(13)$ \\
\hline Direct current shocks administered & $2(6)$ & $2(7)$ & $4(7)$ & $5(25)$ & $1(5)$ & $6(15)$ \\
\hline \multicolumn{7}{|l|}{ Arrhythmia on chest closure } \\
\hline No, sinus rhythm only & $28(90)$ & $29(97)$ & $57(93)$ & $17(85)$ & $16(80)$ & $33(83)$ \\
\hline Atrial flutter/fibrillation & $2(6)$ & $0(0)$ & $2(3)$ & $2(10)$ & $2(10)$ & $4(10)$ \\
\hline Other $\ddagger$ & $1(3)$ & $1(3)$ & $2(3)$ & $1(5)$ & $2(10)$ & $3(8)$ \\
\hline \multicolumn{7}{|l|}{ Pacing } \\
\hline None & $29(94)$ & $28(93)$ & $57(93)$ & $15(75)$ & $14(70)$ & $29(73)$ \\
\hline Single chamber & $1(3)$ & $0(0)$ & $1(2)$ & $4(20)$ & $4(20)$ & $8(20)$ \\
\hline Dual chamber & $1(3)$ & $2(7)$ & $3(5)$ & $1(5)$ & $2(10)$ & $3(8)$ \\
\hline $\begin{array}{l}\text { No additional drugs administered } \\
\text { intraoperatively }\end{array}$ & $29(100)$ & $29(100)$ & $58(100)$ & $19(100)$ & $20(100)$ & $39(100)$ \\
\hline \multicolumn{7}{|l|}{ Postoperative details } \\
\hline HCT on return from theatre $(\%)$ & $29.3 \pm 4.7$ & $29.0 \pm 3.6$ & $29.2 \pm 4.1$ & $28.2 \pm 5.4$ & $28.1 \pm 3.3$ & $28.1 \pm 4.4$ \\
\hline $\begin{array}{l}\text { Temperature on return from theatre } \\
\left({ }^{\circ} \mathrm{C}\right)\end{array}$ & $36.4 \pm 0.5$ & $36.2 \pm 0.5$ & $36.3 \pm 0.5$ & $35.9 \pm 0.5$ & $35.8 \pm 0.3$ & $35.9 \pm 0.4$ \\
\hline Total ventilation time $(\mathrm{h}) \S$ & $6.6(4.9-8.0)$ & $7.4(6.6-12.2)$ & $7.2(5.6-9.5)$ & $6.8(4.8-8.9)$ & $6.7(5.0-8.0)$ & $6.8(5.0-8.6)$ \\
\hline Time on the ward before discharge $(\mathrm{h}) \|$ & $89.0(51.0-120.0)$ & $92.6(49.8-141.5)$ & $90.8(51.0-137.0)$ & $70.0(26.5-106.3)$ & $94.2(71.0-116.7)$ & $91.0(46.3-114.3)$ \\
\hline Length of hospital stay (d) & $6.0(5.0-9.0)$ & $6.0(6.0-9.0)$ & $6.0(5.0-9.0)$ & $7.0(6.0-7.0)$ & $6.0(5.0-9.0)$ & $6.0(6.0-8.0)$ \\
\hline
\end{tabular}


TABLE E6. Additional intraoperative and postoperative details

\begin{tabular}{|c|c|c|c|}
\hline Intra-operative/post-operative characteristic & Randomized to propofol $(n=51)$ & Randomized to intralipid $(\mathbf{n}=\mathbf{5 0})$ & Overall $(n=101)$ \\
\hline \multicolumn{4}{|l|}{ Intraoperative details } \\
\hline \multicolumn{4}{|l|}{ Cardioplegia infusion mode* } \\
\hline Antegrade & $35(70)$ & $34(68)$ & $69(69)$ \\
\hline Retrograde and antegrade & $15(30)$ & $16(32)$ & $31(31)$ \\
\hline Intermittent infusion* & $50(100)$ & $50(100)$ & $100(100)$ \\
\hline \multicolumn{4}{|l|}{ Blood saving techniques } \\
\hline Tranexamic acid & $47(92)$ & $48(96)$ & $95(94)$ \\
\hline If yes, dose (g) & $2.0(2.0-4.0)$ & $2.0(2.0-3.4)$ & $2.0(2.0-4.0)$ \\
\hline Pump blood given & $45(88)$ & $50(100)$ & $95(94)$ \\
\hline If yes, pump blood washed & $2(4)$ & $1(2)$ & $3(3)$ \\
\hline Inotropic support & $6(12)$ & $3(6)$ & $9(9)$ \\
\hline Noradrenaline & $4(8)$ & $1(2)$ & $5(5)$ \\
\hline Dobutamine & $3(6)$ & $1(2)$ & $4(4)$ \\
\hline Dopamine & $0(0)$ & $1(2)$ & $1(1)$ \\
\hline Enoximone & $1(2)$ & $0(0)$ & $1(1)$ \\
\hline Insulin infusion given post bypass & $9(18)$ & $4(8)$ & $13(13)$ \\
\hline Intraoperative vasodilator used & $3(6)$ & $5(10)$ & $8(8)$ \\
\hline Direct current shocks administered & $7(14)$ & $3(6)$ & $10(10)$ \\
\hline \multicolumn{4}{|l|}{ Arrhythmia on chest closure } \\
\hline No, sinus rhythm only & $45(88)$ & $45(90)$ & $90(89)$ \\
\hline Atrial flutter/fibrillation & $4(8)$ & $2(4)$ & $6(6)$ \\
\hline Other $\dagger$ & $2(4)$ & $3(6)$ & $5(5)$ \\
\hline Pacing & $7(14)$ & $8(16)$ & $15(15)$ \\
\hline None & $44(86)$ & $42(84)$ & $86(85)$ \\
\hline Single chamber & $5(10)$ & $4(8)$ & $9(9)$ \\
\hline Dual chamber & $2(4)$ & $4(8)$ & $6(6)$ \\
\hline No additional drugs administered intraoperatively & $48(100)$ & $49(100)$ & $97(100)$ \\
\hline \multicolumn{4}{|l|}{$\begin{array}{l}\text { Conduit graft type (coronary artery bypass } \\
\text { grafting participants only) } \ddagger\end{array}$} \\
\hline Saphenous vein & $57(64)$ & $55(63)$ & $112(63)$ \\
\hline Radial artery & $3(3)$ & $3(3)$ & $6(3)$ \\
\hline Left internal thoracic artery & $28(31)$ & $28(32)$ & $56(32)$ \\
\hline Right internal thoracic artery & $1(1)$ & $2(2)$ & $3(2)$ \\
\hline \multicolumn{4}{|l|}{ Postoperative details } \\
\hline HCT on return from theatre $(\%)$ & $28.9 \pm 4.9$ & $28.6 \pm 3.5$ & $28.8 \pm 4.3$ \\
\hline Temperature on return from theatre $\left({ }^{\circ} \mathrm{C}\right)$ & $36.2 \pm 0.5$ & $36.0 \pm 0.5$ & $36.1 \pm 0.5$ \\
\hline
\end{tabular}


TABLE E7. Troponin T (ng/L) concentrations

\begin{tabular}{|c|c|c|}
\hline Troponin T sample time & $\begin{array}{c}\text { Randomized to } \\
\text { propofol }(n=51)\end{array}$ & $\begin{array}{c}\text { Randomized to } \\
\text { intralipid }(\mathbf{n}=\mathbf{5 0})\end{array}$ \\
\hline \multicolumn{3}{|l|}{ Preoperative } \\
\hline$<14$ ng/L & $30(60)$ & $34(69)$ \\
\hline$\geq 14 \mathrm{ng} / \mathrm{L}$ & $20(40)$ & $15(31)$ \\
\hline Preoperative ( $\geq 14 \mathrm{ng} / \mathrm{L}$ only) & $21.0(15.0-24.0)$ & $20.0(15.0-29.0)$ \\
\hline \multicolumn{3}{|l|}{ After chest closure (h) } \\
\hline 1 & $393.0(298.0-597.0)$ & $486.0(360.0-571.0)$ \\
\hline 6 & $552.0(396.0-827.0)$ & $616.5(492.5-704.0)$ \\
\hline 12 & $434.0(350.5-651.5)$ & $497.0(419.0-607.0)$ \\
\hline 24 & $385.0(263.0-448.0)$ & $395.0(300.0-507.3)$ \\
\hline 48 & $302.7(211.0-378.0)$ & $280.5(222.0-367.0)$ \\
\hline
\end{tabular}

TABLE E8. Lactate concentrations $(\mathrm{mmol} / \mathrm{L})$ and $\mathrm{pH}$ levels

\begin{tabular}{lccccc}
\hline & \multicolumn{2}{c}{ Lactate } & & \multicolumn{2}{c}{$\mathbf{p H}$} \\
\cline { 2 - 3 } Lactate/pH sample time & $\begin{array}{c}\text { Randomized to propofol } \\
(\mathbf{n}=\mathbf{5 1})\end{array}$ & $\begin{array}{c}\text { Randomized to intralipid } \\
(\mathbf{n}=\mathbf{5 0})\end{array}$ & & $\begin{array}{c}\text { Randomized to propofol } \\
(\mathbf{n}=\mathbf{5 1})\end{array}$ & $\begin{array}{c}\text { Randomized to intralipid } \\
(\mathbf{n}=\mathbf{5 0})\end{array}$ \\
\hline Preoperative & $0.8(0.5-1.1)$ & $0.8(0.6-1.0)$ & $7.416 \pm 0.031$ & $7.426 \pm 0.039$ \\
After chest closure (h) & & & & \\
1 & $1.2(0.9-1.4)$ & $1.0(0.7-1.1)$ & & $7.373 \pm 0.047$ & $7.369 \pm 0.058$ \\
6 & $1.1(0.9-1.6)$ & $1.1(0.8-1.4)$ & & $7.339 \pm 0.046$ & $7.347 \pm 0.054$ \\
12 & $1.5(1.0-1.7)$ & $1.2(1.0-1.5)$ & & $7.339 \pm 0.047$ & $7.351 \pm 0.055$ \\
24 & $1.3(1.1-1.8)$ & $1.2(1.0-1.6)$ & & $7.336 \pm 0.044$ & $7.351 \pm 0.048$ \\
48 & $1.2(0.9-1.5)$ & $1.2(1.0-1.6)$ & & $7.356 \pm 0.041$ & $7.367 \pm 0.060$ \\
\hline
\end{tabular}

Values are presented as median (interquartile range) or mean \pm standard deviation. Missing data (numbers for propofol and intralipid groups respectively): lactate preoperatively: $1(1,0)$, lactate after chest closure: $1 \mathrm{~h}: 2(1,1), 6 \mathrm{h:} 1(1,0), 12 \mathrm{~h}: 1(1,0), 24 \mathrm{~h}: 5(2,3), 48 \mathrm{~h}: 23(9,14)$, and pH after chest closure: $1 \mathrm{h:} 1(0,1), 12 \mathrm{h:} 1(1,0), 24 \mathrm{h:} 5(2,3), 48 \mathrm{h:} 25$ $(11,14)$. 
TABLE E9. Renal function, measured by serum creatinine ( $\mu \mathrm{mol} / \mathrm{L})$, by surgical stratum

\begin{tabular}{lccccc}
\hline & \multicolumn{2}{c}{ Coronary artery bypass grafting } & & \multicolumn{2}{c}{ Aortic valve replacement } \\
\cline { 2 - 3 } $\begin{array}{c}\text { Serum creatinine } \\
\text { sample time }\end{array}$ & $\begin{array}{c}\text { Randomized to propofol } \\
(\mathbf{n}=\mathbf{3 1})\end{array}$ & $\begin{array}{c}\text { Randomized to intralipid } \\
(\mathbf{n}=\mathbf{3 0})\end{array}$ & $\begin{array}{c}\text { Randomized to propofol } \\
(\mathbf{n}=\mathbf{2 0})\end{array}$ & $\begin{array}{c}\text { Randomized to intralipid } \\
(\mathbf{n}=\mathbf{2 0})\end{array}$ \\
\hline $\begin{array}{l}\text { Preoperative } \\
\text { After chest closure (h) }\end{array}$ & $88.0(74.0-105.0)$ & $88.0(78.0-92.0)$ & $88.5(81.5-106.5)$ & $83.5(72.0-95.5)$ \\
1 & $91.0(77.0-98.0)$ & $84.0(78.0-96.0)$ & & \\
6 & $96.0(81.0-113.0)$ & $90.5(82.0-100.0)$ & & $101.0(94.0-119.0)$ & $83.5(67.0-91.0)$ \\
12 & $98.0(85.0-112.0)$ & $94.0(85.0-102.0)$ & & $115.0(97.0-127.0)$ & $90.5(78.0-96.0)$ \\
24 & $110.0(90.0-147.0)$ & $97.0(90.5-118.0)$ & & $129.0(107.0-157.0)$ & $94.0(82.0-109.0)$ \\
48 & $112.0(87.0-165.0)$ & $97.0(81.0-114.5)$ & $119.0(104.0-145.0)$ & $92.5(77.0-111.0)$ \\
\hline
\end{tabular}

Values are presented as median (interquartile range). Missing data (numbers for coronary artery bypass grafting propofol, coronary artery bypass grafting intralipid, aortic valve replacement propofol and aortic valve replacement intralipid groups respectively): preoperative: $1(0,1,0,0)$ and after chest closure: $1 \mathrm{~h}: 1(0,1,0,0), 6 \mathrm{~h}: 3(0,2,1,0), 12 \mathrm{~h}: 4(2$, $1,1,0), 24$ h: $4(0,2,2,0)$, and 48h: $3(1,2,0,0)$ 
TABLE E10. Quality-of-life scores

\begin{tabular}{|c|c|c|}
\hline Measure & $\begin{array}{c}\text { Randomized } \\
\text { to propofol }\end{array}$ & $\begin{array}{l}\text { Randomized } \\
\text { to intralipid }\end{array}$ \\
\hline EQ-5D VAS & $(\mathbf{n}=\mathbf{5 1})$ & $(\mathbf{n}=\mathbf{5 0})$ \\
\hline Preoperative & $68 \pm 21.0$ & $66 \pm 20.8$ \\
\hline 3 mo postoperative & $77 \pm 19.2$ & $80 \pm 12.4$ \\
\hline CROQ & $(\mathbf{n}=\mathbf{3 1})$ & $(\mathbf{n}=\mathbf{3 0})$ \\
\hline \multicolumn{3}{|l|}{ Core total score } \\
\hline Preoperative & $50.0(44.3-54.8)$ & $52.1(44.9-57.7)$ \\
\hline 3 mo postoperative & $51.6(45.9-55.6)$ & $52.9(48.1-55.0)$ \\
\hline \multicolumn{3}{|l|}{ Symptoms score } \\
\hline Preoperative & $67.9(54.7-85.7)$ & $78.6(50.0-89.9)$ \\
\hline 3 mo postoperative & $94.7(82.1-100.0)$ & $96.4(91.7-100.0)$ \\
\hline \multicolumn{3}{|c|}{ Physical functioning score } \\
\hline Preoperative & $75.0(50.0-87.5)$ & $68.8(40.7-96.9)$ \\
\hline 3 mo postoperative & $81.3(68.8-100.0)$ & $87.5(75.0-100.0)$ \\
\hline \multicolumn{3}{|c|}{ Cognitive functioning score } \\
\hline Preoperative & $80.0(60.0-93.3)$ & $86.7(66.7-93.3)$ \\
\hline 3 mo postoperative & $90.0(66.7-100.0)$ & $86.7(73.3-100.0)$ \\
\hline \multicolumn{3}{|c|}{ Psychosocial functioning score } \\
\hline Preoperative & $65.9(51.8-85.7)$ & $73.2(53.6-91.1)$ \\
\hline 3 mo postoperative & $86.6(67.9-96.4)$ & $87.5(75.0-94.6)$ \\
\hline \multicolumn{3}{|l|}{ Satisfaction score } \\
\hline 3 mo postoperative & $84.7(72.2-95.8)$ & $83.3(72.2-95.8)$ \\
\hline \multicolumn{3}{|l|}{ Adverse events score } \\
\hline 3 mo postoperative & $89.8(70.5-95.5)$ & $87.5(79.5-95.5)$ \\
\hline MLHFQ & $(\mathbf{n}=\mathbf{2 0})$ & $(\mathbf{n}=\mathbf{2 0})$ \\
\hline \multicolumn{3}{|l|}{ Overall score } \\
\hline Preoperative & $28.5(11.0-54.0)$ & $27.0(11.0-35.5)$ \\
\hline 3 mo postoperative & $15.0(5.0-32.0)$ & $12.5(3.0-29.0)$ \\
\hline \multicolumn{3}{|l|}{ Physical dimension score } \\
\hline Preoperative & $15.5(5.5-24.0)$ & $16.0(8.5-21.0)$ \\
\hline 3 mo postoperative & $8.0(3.0-16.0)$ & $6.0(1.0-15.0)$ \\
\hline \multicolumn{3}{|c|}{ Emotional dimension score } \\
\hline Preoperative & $4.5(1.5-12.5)$ & $4.0(1.5-8.0)$ \\
\hline 3 mo postoperative & $3.0(0.0-8.0)$ & $4.0(0.0-7.0)$ \\
\hline \multicolumn{3}{|c|}{$\begin{array}{l}\text { Values are presented as mean } \pm \text { standard deviation or median (interquartile range). } \\
\text { Missing data (numbers for propofol and intralipid groups, respectively): EQ-5D } \\
\text { VAS score preoperatively: } 1(0,1) \text {, EQ-5D VAS score postoperatively: } 2(1,1) \text {, } \\
\text { CROQ core score preoperatively: } 1(0,1) \text {, CROQ core score postoperatively: } 1(1 \text {, } \\
\text { 0), CROQ symptoms score preoperatively: } 1(0,1) \text {, CROQ symptoms score postop- } \\
\text { eratively: } 2(1,1) \text {, CROQ physical functioning score preoperatively: } 2(0,2) \text {, CROQ } \\
\text { physical functioning score post-operatively: } 2(1,1) \text {, CROQ cognitive functioning } \\
\text { score preoperatively: } 1(0,1) \text {, CROQ cognitive functioning score postoperatively: } 1 \\
(1,0) \text {, CROQ psychological functioning score preoperatively: } 1(0,1) \text {, CROQ psy- } \\
\text { chological functioning score postoperatively: } 1(1,0) \text {, CROQ satisfaction score post- } \\
\text { operatively: } 1(1,0) \text {, CROQ adverse events score postoperatively: } 1(1,0) \text {, MLHFQ } \\
\text { overall score postoperatively: } 1(1,0) \text {, MLHFQ physical dimension score postopera- } \\
\text { tively: } 1(1,0) \text {, MLHFQ emotional dimension score postoperatively: } 1(1,0) \text {. VAS, } \\
\text { Visual analog scale; CROQ, Coronary Revascularization Outcome Questionnaire; } \\
\text { MLHFQ, Minnesota Living with Heart Failure Questionnaire. }\end{array}$} \\
\hline
\end{tabular}


TABLE E11. EQ-5D utility score by surgical stratum

Coronary artery bypass grafting

Aortic valve replacement

\begin{tabular}{|c|c|c|c|c|}
\hline \multirow[b]{2}{*}{$\begin{array}{c}\text { EQ-5D questionnaire } \\
\text { time point }\end{array}$} & & \\
\hline & $\begin{array}{c}\text { Randomized to } \\
\text { propofol }(\mathrm{n}=\mathbf{3 1})\end{array}$ & $\begin{array}{c}\text { Randomized to } \\
\text { intralipid }(n=30)\end{array}$ & $\begin{array}{c}\text { Randomized to } \\
\text { propofol }(n=20)\end{array}$ & $\begin{array}{c}\text { Randomized to } \\
\text { intralipid }(n=20)\end{array}$ \\
\hline Preoperative & $0.796(0.689-1.000)$ & $0.727(0.620-0.850)$ & $0.867(0.638-1.000)$ & $0.760(0.620-1.000)$ \\
\hline 3 mo postoperative & $0.814(0.727-1.000)$ & $0.796(0.689-1.000)$ & $0.788(0.586-0.925)$ & $1.000(0.691-1.000)$ \\
\hline
\end{tabular}

TABLE E12. EQ-5D categorical responses

\begin{tabular}{|c|c|c|c|c|}
\hline \multirow[b]{2}{*}{ Category } & \multicolumn{2}{|c|}{ Baseline } & \multicolumn{2}{|c|}{3 mo postoperation } \\
\hline & $\begin{array}{c}\text { Randomized } \\
\text { to propofol }(n=51)\end{array}$ & $\begin{array}{c}\text { Randomized } \\
\text { to intralipid }(\mathbf{n}=\mathbf{5 0}) \\
\end{array}$ & $\begin{array}{c}\text { Randomized } \\
\text { to propofol }(n=51)\end{array}$ & $\begin{array}{c}\text { Randomized } \\
\text { to intralipid }(n=50)\end{array}$ \\
\hline \multicolumn{5}{|l|}{ Mobility } \\
\hline No problems & $34(67)$ & $24(50)$ & $32(64)$ & $35(71)$ \\
\hline Some problems & $17(33)$ & $22(46)$ & $16(32)$ & $14(29)$ \\
\hline Confined to bed & $0(0)$ & $2(4)$ & $2(4)$ & $0(0)$ \\
\hline \multicolumn{5}{|l|}{ Self-care } \\
\hline No problems & $46(90)$ & $45(94)$ & $45(90)$ & $45(92)$ \\
\hline Some problems & $5(10)$ & $2(4)$ & $4(8)$ & $4(8)$ \\
\hline Unable to wash/dress & $0(0)$ & $1(2)$ & $1(2)$ & $0(0)$ \\
\hline \multicolumn{5}{|l|}{ Usual activities } \\
\hline No problems & $25(49)$ & $25(52)$ & $30(60)$ & $28(57)$ \\
\hline Some problems & $20(39)$ & $21(44)$ & $18(36)$ & $21(43)$ \\
\hline Unable to perform usual activities & $6(12)$ & $2(4)$ & $2(4)$ & $0(0)$ \\
\hline \multicolumn{5}{|l|}{ Pain/discomfort } \\
\hline No pain/discomfort & $28(55)$ & $23(48)$ & $27(54)$ & $25(51)$ \\
\hline Moderate pain/discomfort & $21(41)$ & $25(52)$ & $21(42)$ & $21(43)$ \\
\hline Extreme pain/discomfort & $2(4)$ & $0(0)$ & $2(4)$ & $3(6)$ \\
\hline \multicolumn{5}{|l|}{ Anxiety/depression } \\
\hline Not anxious/depressed & $36(72)$ & $27(56)$ & $40(80)$ & $34(71)$ \\
\hline Moderately anxious/depressed & $14(28)$ & $18(38)$ & $9(18)$ & $14(29)$ \\
\hline Extremely anxious/depressed & $0(0)$ & $3(6)$ & $1(2)$ & $0(0)$ \\
\hline
\end{tabular}


TABLE E13. Further details on unexpected serious adverse events (SAEs) and deaths

\begin{tabular}{|c|c|c|c|c|c|c|}
\hline Study ID & $\begin{array}{c}\text { Randomized } \\
\text { allocation }\end{array}$ & Event & Timing of SAE & $\begin{array}{l}\text { Maximum } \\
\text { intensity }\end{array}$ & Relatedness & Reason event SAE \\
\hline 1 & Propofol & Diverticulum & Postdischarge & Moderate & $\begin{array}{l}\text { Unlikely to } \\
\text { be related }\end{array}$ & $\begin{array}{r}\text { Event resulted in } \\
\text { hospitalization }\end{array}$ \\
\hline 2 & Propofol & $\begin{array}{l}\text { Peripheral } \\
\text { ischemia }\end{array}$ & Presurgery & Moderate & $\begin{array}{l}\text { Unlikely to } \\
\text { be related }\end{array}$ & $\begin{array}{l}\text { Event resulted in persistent/ } \\
\text { significant disability/ } \\
\text { incapacity }\end{array}$ \\
\hline 3 & Propofol & Chest pain & Postdischarge & Severe & Not related & $\begin{array}{l}\text { Event resulted in persistent/ } \\
\text { significant disability/ } \\
\text { incapacity } \\
\text { AND hospitalization }\end{array}$ \\
\hline 4 & Intralipid & Bradycardia & $\begin{array}{c}\text { Postsurgery but } \\
\text { predischarge }\end{array}$ & Moderate & $\begin{array}{l}\text { Unlikely to } \\
\text { be related }\end{array}$ & $\begin{array}{l}\text { Event prolonged ongoing } \\
\text { hospitalization }\end{array}$ \\
\hline 5 & Intralipid & Cholecystectomy & Postdischarge & Moderate & Not related & $\begin{array}{l}\text { Event resulted in persistent/ } \\
\text { significant disability/ } \\
\text { incapacity } \\
\text { AND hospitalization }\end{array}$ \\
\hline 6 & Intralipid & $\begin{array}{l}\text { Cardiac failure } \\
\text { congestive }\end{array}$ & Postdischarge & Severe & $\begin{array}{l}\text { Unlikely to } \\
\text { be related }\end{array}$ & $\begin{array}{l}\text { Event resulted in } \\
\text { hospitalization }\end{array}$ \\
\hline 7 & Propofol & Maculopathy & Postdischarge & Moderate & $\begin{array}{l}\text { Unlikely to } \\
\text { be related }\end{array}$ & $\begin{array}{l}\text { Event resulted in persistent/ } \\
\text { significant disability/ } \\
\text { incapacity }\end{array}$ \\
\hline 8 & Intralipid & Paraesthesia & $\begin{array}{c}\text { Postsurgery but } \\
\text { predischarge }\end{array}$ & Moderate & $\begin{array}{l}\text { Unlikely to } \\
\text { be related }\end{array}$ & $\begin{array}{l}\text { Event resulted in persistent/ } \\
\text { significant disability/ } \\
\text { incapacity }\end{array}$ \\
\hline \multirow[t]{2}{*}{9} & Propofol & $\begin{array}{l}\text { Cardiac failure } \\
\text { congestive }\end{array}$ & Postdischarge & Severe & $\begin{array}{l}\text { Unlikely to } \\
\text { be related }\end{array}$ & $\begin{array}{l}\text { Event resulted in } \\
\text { hospitalization }\end{array}$ \\
\hline & & $\begin{array}{l}\text { Renal failure } \\
\text { acute }\end{array}$ & Postdischarge & Severe & $\begin{array}{l}\text { Unlikely to } \\
\text { be related }\end{array}$ & $\begin{array}{r}\text { Event resulted in } \\
\text { hospitalization }\end{array}$ \\
\hline
\end{tabular}

